\title{
Design, Fundamental Principles of Fabrication and Applications of Microreactors
}

\author{
Adama A. Bojang $(\mathbb{D}$ and Ho-Shing $\mathrm{Wu}$ * (10) \\ Department of Chemical Engineering and Materials Science, Yuan Ze University, 135 Yuan Tung Road Chung Li, \\ Taoyuan 32003, Taiwan; zazafj1990@gmail.com \\ * Correspondence: cehswu@saturn.yzu.edu.tw; Tel.: +886-3-4638800-2564
}

Received: 4 June 2020; Accepted: 22 July 2020; Published: 25 July 2020

check for updates

\begin{abstract}
This study highlights the development of small-scale reactors, in the form of microstructures with microchannel networking. Microreactors have achieved an impressive reputation, regarding chemical synthesis ability and their applications in the engineering, pharmaceutical, and biological fields. This review elaborates on the fabrication, construction, and schematic fundamentals in the design of the microreactors and microchannels. The materials used in the fabrication or construction of the microreactors include silicon, polymer, and glass. A general review of the application of microreactors in medical, biological, and engineering fields is carried out and significant improvements in these areas are reported. Finally, we highlight the flow patterns, mixing, and scaling-up of multiphase microreactor developments, with emphasis on the more significant industrial applications.
\end{abstract}

Keywords: microreactor; pharmaceutical; construction; laminar flow; fabrication

\section{Introduction}

Modernization in engineering has led to remarkable improvements in small-scale reactors and microreactor-based $(<1 \mathrm{~mm})$ application models. Microreactor technology has improved over the years, signifying the new standard of microreactors for batch operations, prevailing over macrosize constant reactors. A microreactor is an instrument that processes chemical reactions within capillary channels [1]. The reactor is customarily a continuous flow reactor, as compared with a batch reactor. Microreactors offer many advantages over large-scale reactors, as related to energy efficiency, the velocity of reactions, and the total output of products, as well as having the most straightforward methodology management [2]. Microreactors can also be used to boost various unit operations and reactions in microspace. Hence, innovative microfluidic devices have been utilized in an immense variety of processes, due to their expedience and potential range of applications. The best microreactors are comprised of micrometer-sized capillaries less than $1 \mathrm{~mm}$ in diameter or a network of channels leading into a substrate. In 1959, Richard led the development of microreactors by conceptualizing the use of micromachining and microsized relays. Small-scale reactor technology has recently expanded beyond micromachining [2-5]. These studies have shown that microreactors can be used to carry out complex reactions such as esterification, chemical hydrogenation, and free radical chemical reaction synthesis, which entail complex side-chain reactions and some synthetic reaction methods. Suryawanshi et al. described the micromixer, microreactor dimensions, and synthesis products of nanomaterials in microreactors in detail [6]. Microreactors provide pivotal improvements in an analytical chemistry system design, leading to excellent output yield of chemicals, allowing for the viewing of biological cells and amino acids, and having good transportability. Due to these factors, microreactors have improved the theory and application of reaction synthesis in both chemical and medical (pharmaceutical) industries [7-10]. 
At present, researchers and industrialists use several different types of microreactors, which has made it difficult to categorize them, regarding selectivity and performance [11,12]. This effect has led to different construction methods, with respect to the required size, length, and resolution. Moreover, the fabrication of microreactors is under high demand, and there has been increasing pressure on micromachining methods [13]. In the way forward between laboratory and industrial production, small-scale reactors need to combine or integrate numerous compatible mechanisms of operation and industries need to develop simple and efficient processes by developing integrated chips with good design and functionality [14-16]; however, attempting to accomplish these tasks could lead to some challenges in fluid complexities and the management of chemicals. Wohlgemuth et al. have conceded this effect, in microfluidic devices, in the process of output repossession [17]. This work reports the crucial aspects of microreactors, which have seen momentous improvements, from their background in systematic classifications to the high-throughput synthesis of organic or inorganic chemicals, the well-organized transmission of biological cells and amino acids in proteins, the manufacture of convenient expedients, and the investigation of chemical reaction kinetics. Effective microreactor operations depend on many factors, from construction to the mode of functionality, considering modern forms and perspectives. The fundamental and principal mathematical concepts have been described, in detail, by Wang et al. [18].

\section{Construction of a Microreactor}

The bulk of established microfluidic fuel cells have utilized fabrication approaches that have been previously recognized for physical science and microfluidic chips. Characteristically, these devices are comprised of a microchannel, two electrodes, and a liquid-compact maintenance arrangement [19-21]. Microchannels are still classically fabricated, using speedy prototyping, conventional disbursal lithography, and soft lithography protocols [21-24]. By gearing toward microfluidic electric cell devices through side-by-side flowing [19-21], the channel organizations have been formed in polydimethylsiloxane (PDMS) and wrapped in a robust substrate, which housed the conductor configuration. Various channel construction techniques can be found throughout the literature, as mentioned by Kjeang et al. [25]. Industrially, the lenient lithography-based method is performed by pretreating a substrate or using a photoresist layer to improve a silicon wafer, after which a coating is applied. The layers of the microchannel are spin-coated by photoresist materials, which determine the functionality of the layers.

For a steady photoresist mechanism, the coated substrate is gently heated on a hot plate. Measurement of the resolution of the constructed channel is done using CAD software, which contains a photomask and enables high-resolution image print-out. The substrate is then permitted to absorb UV radiation, which develops both the exposed and unexposed parts of the photoresist. The measurement is carried out by the substrate absorbing fluid. A positive decoration shows a proper polymerized photoresist ridge. PDMS is used to duplicate the channel design by molding, followed by exposure to vacuum conditions on a hot plate [19-21,26,27].

Some microfluidic microreactors are compatible in the application of enzymatic biofuel cells (or fuel cells, in general) through the utilization of organic catalysts. Biofuel cells operate or synthesize energy in a redox reaction form by catalyzing macromolecules (glucose) with the use of an organic catalyst $[28,29]$. The total revenue base for microfluidic devices was $\$ 1.8$ billion in 2014, and it is expected to increase by $\$ 7.7$ billion by the year 2020 [30]. The world is advancing in the improvement of the reactor design, in which microreactor fabrication plays a part in both the simulation and analysis of chemical reactions. The industry's growth has been stimulated by the availability of excellent materials at low cost for constructing microreactors. A small-scale reactor is made using different material types (e.g., silicon, glass, steel, and ceramics) in combination with polymers and polymeric materials. Small-scale reactors can be designed as capillary reactors or chip-form reactors, which allows their wide application in different scientific fields possible, as shown in Figure 1. Capillary reactors are designed in terms of size and length, considering the associated fluid properties. In contrast, 
chip-based microreactors are typically designed with mostly silicon, glass, or even certain types of plastic made by micromachining, etching, and lithography methods [8,31,32].

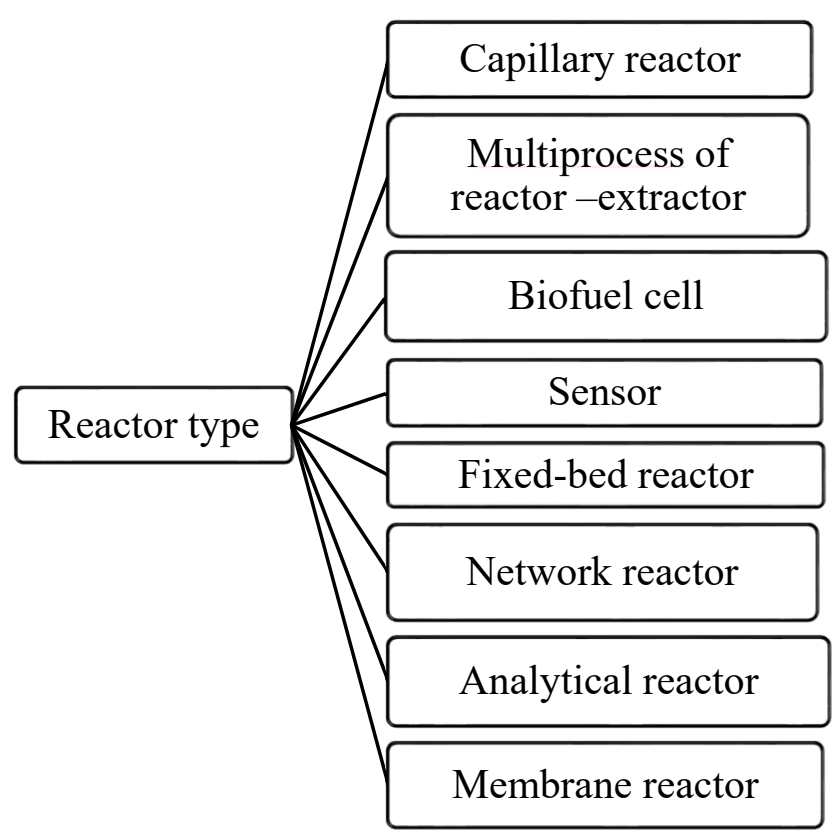

Figure 1. Microreaction applications in different fields of science.

Conversion of ethanol to 1,3-butadiene is an organic reaction that can be carried out using a microreactor; a specific microcapillary reactor has been found to yield high output and a better ethanol conversion rate $[33,34]$. In this process, mass transfer, momentum, and balance are necessary for the efficiency of the reaction, and the reactor is exposed to high temperatures $\left(400{ }^{\circ} \mathrm{C}\right)$. Methanol synthesis has been performed using a copper-based catalyst in a fixed-bed reactor [35]. A novel mesh-type $\gamma-\mathrm{Al}_{2} \mathrm{O}_{3} / \mathrm{Al}$ support was prepared by anodization technology, in order to decrease dimethyl ether yield in methanol steam reformation [36]. As reported by Yen et al., cadmium selenide (CdSe) nanocrystals can be produced in a continuous flow microreactor, which has a hot mixer channel with a capillary within it [37]. The evidence of their experiment explains the nucleation and advancement of the changes in the nanocrystal, demonstrating the ability of the capillary-type microreactor for use in the formation of nanoparticles (nanocrystals). A scale-up study of capillary microreactors for the solvent-free semi-hydrogenation of 2-methyl-3-butyn-2-ol has been reported by Cherkasova et al. [38].

Chip microreactor forms are suitable in the application of microfluidics and can be combined into a simple one-operation unit. They are composed of many channel shapes and forms in order to control the quantity of the volume of the liquid. A different route in the synthesis of a chemical is applicable in multichannel microreactors, considering the network of construction of the channel in a single-chip reactor $[39,40]$. Microreactors can be used for some chemical separation methods, for example, in the separation of an organic solution and a fluorous fluid-based system, as reported by Kralj et al. [41]. Based on the principle of equilibrium, microreactors can separate and extract solvents. This can also be extended to bioenzymatic reactions through the use of a multiprocess microreactor [42]. Some available studies on microreactors, which have made use of batch and stirred reactors, are not applicable to chemical engineering and chemical reactions. However, the construction of small-scale reactors has become more advanced and has been introduced into specific engineering fields, such as the electronics and semiconductor industries [43-45]. Urban et al. presented an electrochemical microsensor system for a multiparametric detection Pt-based electrode by changing the dissolved concentrations of hydrogen peroxide $\left(\mathrm{H}_{2} \mathrm{O}_{2}\right)$ and oxygen $\left(\mathrm{O}_{2}\right)$ inside a direct synthesis membrane microreactor [46]. Chucherd et al. reported the effects of applied voltage in electrospinning for 
nanofiber fabrication, as well as the effects of the thickness of microchannels in the microreactor and initial metal concentration in the feed stream on the extraction efficiency [47].

\subsection{Materials Used in Microreactor Construction}

The construction of small-scale microreactors has usually been interpreted as the combination of devices, in which the passage of liquids occurs, and distinguished organic chemicals in general and bio-organic substances are often disbursed. The key term analytical system has been often used, as these reactors have specific potential operations. Their mode of fabrication provides them many clean and significant potential uses in the chemical field. Due to their high electro-osmotic flow, microreactors can direct fluids from a syringe pump or other sources of hydraulic displacement, which is advantageous in specific separation techniques. The construction of these reactors is carried out using various different materials, such as Si and steel [48-52], as listed in Table 1. To fabricate a microreaction, the specific key material is needed, and the material in question should have significant properties concerning functionality, resistance to high pressure and temperature, the selectivity of the reacting mixture, and its physical properties such as $\mathrm{pH}$, viscosity, and phase (i.e., liquid, solid, or gas), which should all be considered in order to ensure the ease of construction and rapid expansion of production. Silicon is easily attainable and less expensive than other materials, which is why it has been widely used in microreactor construction. In general, silicon has many functions in electronic industries, such as chip fabrication, which make it compatible with the development of small-scale microreactors, due to its flexibility. Silicon reactors can operate some high-demand industrial liquid and gas reaction syntheses. Due to excellent streamflow mechanisms, silicon microreactors can obtain good product yields in some surface reactions. The molding process provides an easy way to construct a microreactor, where the most popular material used in this process is polydimethylsiloxane (PDMS).

Table 1. Merits and demerits of the distinctive constituents used for microreactor construction.

\begin{tabular}{|c|c|c|c|c|}
\hline Materials & & Merits & & Demerits \\
\hline \multirow[t]{3}{*}{ Metal } & 1. & No clean-room necessary & 1. & Auxiliary through noble metals material \\
\hline & 2. & Long-lasting materials & 2. & Concerns with variable pressure descent \\
\hline & 3. & Unshakable fabrication performances & & \\
\hline \multirow[t]{3}{*}{ Glass } & 1. & Good reaction synthesis and flow dynamics & 1. & Trouble in making better aspect-relative structures \\
\hline & 2. & Possibility of better electro-osmotic properties & & \\
\hline & 3. & Endures good functioning condition & & \\
\hline \multirow[t]{3}{*}{ Polymers } & 1. & Low cost & 1. & Organic compatibility \\
\hline & 2. & Disposable microreactors possible & 2. & Good control of heat \\
\hline & 3. & Various fabrication techniques & & \\
\hline \multirow[t]{2}{*}{ Silicon } & 1. & High-precision fabrication & 1. & Costly fabrication methods \\
\hline & 2. & Well-characterized material & 2. & Clean-room needed \\
\hline \multirow[t]{2}{*}{ Ceramic } & 1. & High thermal strength & 1. & Time-consuming \\
\hline & 2. & Good chemical resistance & 2. & Costly manufacturing of components \\
\hline
\end{tabular}

Certain materials, such as silicon, have an excellent laminar flow dynamic system (even under some poor surface conditions), which enables their use as a hypergolic fuel, as indicated by Saksena et al. [53]. Silicon microreactors make these fuels oxidizers, thus having significant applications in chemical industries. Floyd et al. described this phenomenon of laminar flow technique in microreactors, expressing the concept of rapid mass transfer under high-temperature velocities with specificity in liquid-phase reactions [54]. Small-scale silicon microreactors are versatile, regarding the reaction conditions; for example, exothermic gas-phase reactions are generally well-conditioned, as the reactors can allow the smooth flow of heat even at extreme temperatures (i.e., 600-800 ${ }^{\circ} \mathrm{C}$ ) [55]. Some silicon microreactors have been designed to detect the temperature by using temperature-sensing chips in 
the reactor. Due to this functionality of silicon microreactors, they can achieve selectivity and the high conversion of products in different chemical reactions. Apart from silicon, polymers are also essential materials in the construction of microreactors, as they have some basic physical and chemical properties, such as elasticity and formation modes, which are easy to determine and can eventually be used in the fabrication of chip microreactors. Many polymers are available in nature, where the basic properties of many polymers are still under debate; however, some polymers are available for the construction of microreactors, especially for small-scale microfluidic reactors. One such polymer is PDMS, which has different forms, as mentioned in the literature, and is typically synthesized in thermoplastic versions [56-60].

The universal application of PDMS in the microreactor industry has been well-indicated; for instance, in the fabrication of fuel cells reported by Shah et al., where a small-scale reactor was developed by using PDMS in a proton exchange membrane, which can be used as a biofuel cell or for other biosensor devices [61]. Due to the cheap nature of PDMS materials, many microfluidic-based technologies can be developed at a large scale. This is advantageous to the concerned industries, as the rapid mass production increases the production potentials and the realization of the schemes and inventions of researchers, as reported by Azouz et al. in the development of microfluidic cells by means of cyclic olefin copolymerization techniques [56]. In a real sense, polymers are suitable for the manufacturing of microreactors in different forms and shapes; however, they do have limitations in certain aspects. At high temperatures, some polymers can deform during polymerization and might not balance the momentum of energy. These difficulties are experienced in small-scale microreactor biofuel cells (or fuel cells, in general), as they principally operate under the fundamental principles of energy consumption and conservation. There is ordinarily thermal compatibility for small volumes of reactions, which is fascinating.

Glass materials are also a well-organized source for microreactor fabrication due to their natural physical characteristics. They have shown excellent synthetic chemical reaction advancement. Glass materials have some limitations for reactor schematic designs, in terms of the required forms of shape used in the creation of microreactors. Nevertheless, they are suitable for a good-standard chemical process reaction, as they can withstand the typical osmotic pressure and osmotic flow of liquids (polar). In glass reactors, the delocalization of electrons is typically observed, as the electrodes are inserted in solution, thus showing good electro-osmotic flow when a certain voltage is applied [62]. An example of a glass-based reactor has been reported by Tigger et al., which was used for the synthesis of an organic acid [63].

In every chemical reaction, the frequency of colliding particles can be observed kinetically in both linear and non-linear reaction paths. These chemical aspects of reacting species or reacting systems are based on the principles of diffusion and equilibrium, as described in several publications [5,64-67]. The elasticity of materials used in microreactor fabrication must be considered, as an individual reaction that involves high temperature and the reaction enthalpy of the chemical reacting mixtures affect the surface interactions of molecular species; this effect must be addressed, as it is significant for the smooth relationship between the thermodynamics of both the materials and the reacting solvent or medium. Some polymer materials do face thermodynamic hindrances with respect to some chemicals, thus limiting their application (especially in high power generation applications) or operation in microreactors. In the advancement of the electromicroreactor industry, specific polymers can be molded into a fuel reactor that generates power, as detailed by Vican et al., who used an aluminum power generator with the aid of UV-radiation curing. Later on, this mechanism was used in the commercialization of thermal electric operations [68]. The fashioning of microreactors is not limited only to ceramics or polymers - it has also been extended to metals, as they have an active and efficient mode of microreactor construction; however, they have shown some limitations, in terms of physical design, due to the rough surface achieved during principle molding of the reactor. Metal synthesis microreactors have shown effective ways to synthesize nanoparticles; for example, Cu-based microreactors have demonstrated a good output of palladium nanoparticles, which are produced in an 
interrupted (continuous) flow system. These nanoparticles are, then, used in fuel cell operations [69]. The fabricated microreactor can produce a nanoparticle with an appropriate size scale of greater than $5 \mathrm{~nm}$ at the apex reaction function. For the improvement of the physical and chemical selectivity of the palladium nanoparticles, proper mixing of the reacting mixture was necessary, involving the mass transfer mechanism and, eventually, increasing its production. The process can be used for the production of $\mathrm{Pt}$ nanoparticles, where the only difference between the modes of reaction is that $\mathrm{Pt}$ nanoparticles can be produced at room temperature $\left(25-27^{\circ} \mathrm{C}\right)[70]$.

The general fabrication scheme of microreactors has been explained, in detail, by Tsao et al. They based their method on PDMS polymer materials, which generally make it easy to construct microfluidic devices [71,72]. The channel design for PDMS is constructed using the lithography technique. The reaction mixtures of PDMS are micromolded and then interconnected by covalent bonding, which enables more durable compartments [72] (Figure 2). The PDMS is cast into a mold, which is later followed by solidification with the help of chemical agents in a relative ratio for quantitative relation. The solidification temperature is normally $80-85^{\circ} \mathrm{C}$ for a duration of $1-3 \mathrm{~h}$ [73]. Later, the formed PDMS is separated from the micromold. Photoresistors, in combination with rosin, are used to finish the casting. This technique gives a high output of PDMS [73]. The addition of PDMS to the microreactor is a straightforward method, and the layers are discharged accordingly. The PDMS and the microreactor are held together by intermolecular Van der Waals bonds, which makes the combination compact and efficient for chemical reaction applications [74]. For an active process, the PDMS is standardized by treating it with chemical agents to induce Silicon-oxygen bonding in the PDMS layers [75].

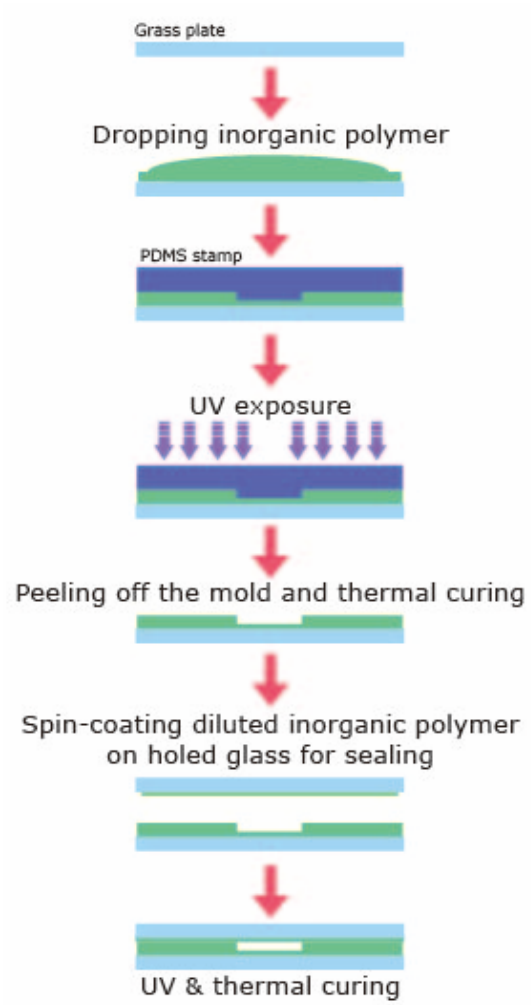

(a)

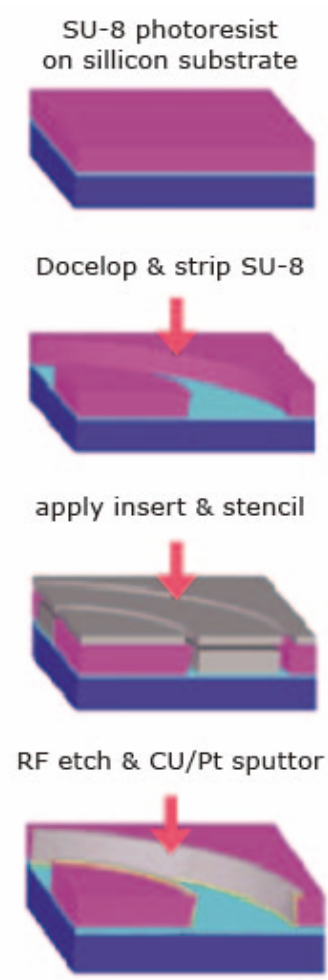

(b)

Figure 2. (a) Using PDMS materials for the manufacture of microreactors [76]. (b) Wet etching application in Pyrex glass with microchannels made of silicon layers [77].

Small-scale reactor construction techniques have improved and gained significant design attention over the years, where certain materials used for the fabrication of microreactors have garnered some 
concern with respect to their effect on the reactant mixture. In some cases, the microreactor may interfere with the reaction solution in the microreactor; typically, this effect is predicted to be inert, as reported in some publications [78]. Nevertheless, the intermolecular changing of some reacting mixtures and the intersurface reactions of the microreactor should be detailed. This is important, as specific chemical syntheses may have unwanted products due to a surface reaction within the microchannels and the reactants. Industrial or laboratory preparation of organic or inorganic chemicals has many application areas; the techniques used in these processes usually are a choice. Thus, the method chosen should be related to the construction materials of the microreactor, the medium in which the reaction is carried out (i.e., gas, liquid, or solid phase), and the modes of synthesis method and extraction of chemicals. In the microreactor industry, the general fabrication and compatibility of materials used in the microreactor should be alienated from the linear flow dynamics in the microchannel $[5,72,78]$.

Mills et al. have detailed the chemical reactions of butadiene using specific microreactors. They used Ti/Fe oxides to catalyze the chemical oxidization of butadiene to various products, which, in turn, increased oxygen conversion [78]. The effect of the materials used for the fabrication of the microreactor plays a vital role in the rate of oxygen conversion, which signifies the concept of the inertness of the microreactor: Some synthetic chemical reactions generate free-radicals which, in turn, propagate in a substitution reaction mechanism form and produce an unwanted outcome. The principal channel design of a microreactor, regarding the area and the ration of superficial area, is key to defining the operation conditions and efficiency of the microreactor [79]. There are different channel designs in different microreactors, as each chemical reaction has a different reaction condition, which means that the channel dimension must be suitable for the reaction process. The chemical reaction of butadiene to furan is performed in a small-dimension microchannel design, which eases the chemical oxidation process. The significant effect of the wall surface ratio within the microreactor in relation to the reacting species determines the operational performance of the microreactor and the conversion output of furan from the chemical oxidation of butadiene. The rate of reaction is determined by the surface area of the microreactor channel, which, in turn, depends on the volume of chemical substances to be synthesized. This method determines the total production output of the microreactor and, hence, is significantly relevant to the chemical industry $[6,75,80]$.

Ceramic microreactors are applicable in specific chemical syntheses or reactions in which metal or polymer systems cannot be used, as ceramics have particular properties (e.g., thermal and chemical resistance), as mentioned by Knitter et al. [81]. Nevertheless, the use of ceramic microcomponents is usually non-ideal, due to the long and expensive production of elements adhering to model specifications (typically at the micrometer scale). An encouraging answer to this downside may be a speedy prototyping method chain, comprised of the quick and accurate fabrication of ceramic elements down to the micrometer accuracy, by relating stereo-lithography with lower pressure ceramic injection molding. The swiftness and versatility of such a method may permit the rapid expansion and production of ceramic elements as practical models or in small sequences. For use in chemical microreactor technology, a standard ceramic microreactor with inner magnitudes within the submillimeter range has been industrialized.

\subsection{Manufacturing Methods of Microreactors}

Many techniques for the construction of microreactors, which meet the standards of large-scale production of synthetic chemicals exist, hence increasing the economic impacts of the chemical industry. Some techniques, such as micromachining, etching (wet) molding, and lithography, among others, have been used in the construction of microreactors [82-84]. The most common methods applicable to the design of microreactors are micromachining, lithography, electroplating, molding (e.g., lithographic, galvanoforming, and abforming), and etching. 


\subsubsection{Etching Methods for Microreactor Construction}

Generally, etching involves removing materials from a substance called a substrate. It can be divided into two main forms: wet etching and dry etching. The application of wet etching is generally done in a laboratory for experimental purposes and is applicable to glasswork and the development of microchannels for laminar flow systems. High-performance operations are needed for dry etching, as it involves significant capital and is typically applied industrially for large-scale production [85]. A photosensor is used during etching, and this process typically refers to metals. The photosensor is used in combination with a mask, in which the molecular layer is present and leads the photosensor to the source of light, thus aiding the etching process. Many photosensors are used in etching applications.

Typically, there are two parts of a material to be exposed to light. The exposed part undergoes polymerization, while the unexposed portion is directly dissolved in a chemical solution such that the material has two parts: one soluble and the other insoluble [3]. The ratio of abundance matters in wet etching; thus, the highest is taken to be 0.5-0.6. A standard ratio is yet to be determined in dry etching, as the method is costly. Wet etching uses an isotopic abundance system to determine the half-circular structure visible on the wet solvent. Pyrex glass demonstrates an excellent example of wet etching (Figure 3). Meanwhile, dry etching can form many geometric structures in many shapes and ratios. The construction of different microchannel sizes and forms has been detailed by Pattek et al. and Suryawanshi et al. [6,85].

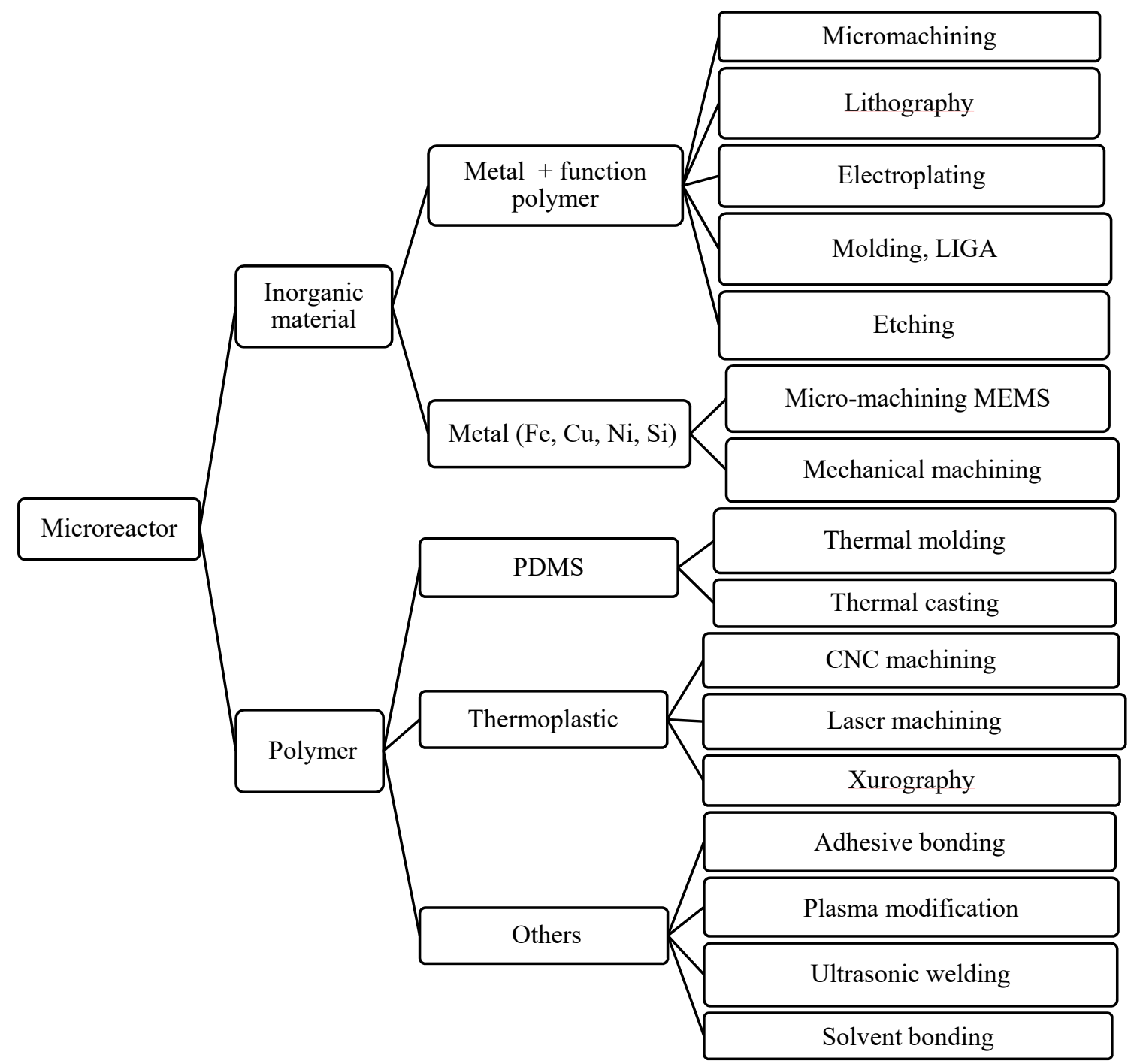

Figure 3. Materials and fabrication of microreactors. 
Most etching applications use a liquid medium that is inserted into a big tub of etchant that should be stressed under proper management. Buffered acid is mostly preferred to perform etching. Silicon etching is performed on semiconducting material substances $[16,86]$. Wet etching is used as an etching method for solid materials under an excessive chemical reaction. Throughout these processes, either the substrate is placed within the reactant, or the reactant is sprayed on the substrate. Wet etching processes are principally identical, independent of crystalline orientation [11,67]. High selectivity implies that the print rate powerfully depends on the incised material. To imprint the crystalline structure, an attacked semi-conducting material (e.g., $\mathrm{Si}$ ) is maintained additionally within the locality of the surface $[1,10,76]$. Anisotropic printing or etching is when the plasma etches perpendicularly and in one direction, whereas isotropic etching is when the plasma etches in all directions. Anisotropic and isotropic etchings have been used to accomplish Thierry's low-pressure plasma systems $[18,87,88]$.

Selectivity is vital during the etching process, as it determines the rate at which the substance is etched. Selectivity varies in wet etching, mostly between the photosensor and the materials or substance $[89,90]$. Materials can be etched in some directions (horizontally or vertically) at different rates. However, for dry etching, the plasma is etched at a specific position (basically by anisotropic etching); this is also called plasma etching.

\subsubsection{Micromachining Method for Microconstruction}

Industrially, micromachining has many operational units that involve the construction, application, and production of small-scale microelectronic systems involving microreactions ranging from microfluidic devices to other types of microreactors. The general term used for such technologies is micro-electro-mechanical systems (or, in short, MEMS). These technologies can produce many kinds of small-scale reactors, especially for the chemical synthesis of both organic and inorganic chemicals of various qualities and quantities [91,92]. In some sense, micromachining can involve the physical drilling of a substance with the aid of an electronic beam instrument $[16,93]$. This technique is used in the industrial production of microreactors, as it is essential in creating structural layers in the microchannel and forming small channels, thus making the microreactor effective and capable of performing multipurpose analyses in every applicable field. The best form of application of micromachining is in semiconductor companies, where the process can help in the mass production of microreactors $[14,94,95]$.

Moreover, micromachining is a useful technique for the fabrication of small-scale reactors, involving many grinding steps to create specific shapes and forms that need several edges and specific geometries. Depending on the materials used, it is sometimes easier to develop the reactor if the material is flexible or less elastic. This technology is operational at a lower cost, compared to other techniques used for microreactor production. A well-known method used in changing the integrity of a material is by exposing it to high temperatures. This helps to melt (evaporate or decompose) the material to change its form from one phase to another for secure processing. This can be done by either optical device machining or mechanical machining $[15,96,97]$. For good surface structure, copper materials can deliver advantageous surface structure layers by mechanical machining [7,72]. Radiation is also an excellent method to create substances for the fabrication of microreactors, specifically laser radiation. Depending on the ductility of the materials or metals (e.g., $\mathrm{Cu}$ and Ni), specific tools such as diamond cutters (Figure 3) are used to cut hard metal materials. Drills are also used to cut hard materials or substances in micromachining $[95,98]$.

2.2.3. Lithography, Electroplating, and Molding or Lithography, Galvanoforming, and Abforming (LIGA) Methods

The development of these technologies started in Germany, with the name LIGA (or lithography, electroplating, and molding). This technique has proved to be useful, as it can be applied to many types of materials, ranging from metal substances to polymer derivatives and even plastic materials. As the name, lithography, implies, this technology employs electronic $X$-ray radiation to aid in the 
molding or graphing of materials to specific forms [78,90]. Generally, this technique can be divided into three necessary steps: (i) pattern transfer to a photosensor (which is usually a resin-type material), (ii) followed by electroplating of the material's surface area by removing some structural layers, and (iii) withdrawal of the photoirradiation, which is provided by the photoresistor or photosensor [10]. Microreactors can be used in biological application reactions, such as for the extraction of DNA in organisms. Effenhauser et al. constructed a PDMS-silicon-based microreactor for the chemical extraction of DNA [99], in which the microchannels were made up of silicon-semiconductor substances. They used PDMS techniques for the operation condition of the fabrication process. The fundamental processing technique involved lithography, electroplating, and molding.

\section{Schematic Fundamentals and Approaches in the Microreactor's Design}

Economically, the manufacturing of microreactors varies in both production application and functionality, as they are based on different schematic fundamentals $[5,66]$. As the design and operation of microreactors are based on the mathematical and engineering conceptualization principles of Laminar continuous flow, it is typically a challenge to synthesize chemicals in microreactors due to these effects. The application of fundamental data is usually a challenge industrially due to different processing styles and reactor design concepts. Still, the batch date makes it is easy to minimize the problem. As microreactors operate on small surface area concepts, which means the frequency of colliding molecules is high kinetically, this aids the speed of production of the final product. Microreactors can perform multitask chemical reactions and, therefore, are preferable for the mass production of synthetic materials or chemicals in industries.

Two types of mixing occur in microreactors: passive mixing and active mixing. The type of mixing is determined mechanically and through some interexternal bonding powers [100]. Active mixing operates by the principle of kinetic energy in the form of electron speeds or hydrofluidic dynamic motion, and the consequent construction design of the microchannel must be specific [101]. However, passive mixing operates on the principle of concentration diffusion over the surface area of the microchannel, and is efficient in many-phase fluid-flowing systems because a pressure drop is attainable with relative diffusion. Industrially, passive mixing is a good mixing process in a multiphase system, which increases the operational output in chemical synthesis [83,101,102].

A passive mixture creates laminar flow conditions in a multifluidic flow system, which leads to a massive increase in surface-area for concentration diffusion. Mixing in microreactors is controlled by the lamination system, which is essential for the pressure drop in the microchannels $[11,100,103]$. In many-phase microreactor systems, passive mixing decreases ineffective operational functionality (Table 2). The general movement of fluids in the microchannel takes the form of a continuous flow with passive mixing segments. The laminar flow system in the microreactor is, therefore, termed as a continuous flow or segmented- or disintegrated-flow. Disintegrated flow can occur in both gas and liquid systems, either as a gas-liquid disintegrated flow or liquid-liquid disintegrated flow. In general, the flow profiles of continuous flow with passive mixing are conferred consistently [104]. Solution homogeneity is essential during mixing in microreactors and, thus, for a batch-reactor system. The condition could be a continuous flow, but if the mixing is not passive, it may cause superficial alteration or modification in the chemical reaction conditions.

Conversely, as the fluid usually flows at intervals in the bedded region, the intermolecular diffusional concentration of substances improves compounding. The surface area plays a vital role in continuous flow systems, as it determines the frequency of distribution of substances in different intervals; the reaction conditions also play a part in this. The velocities of molecules in a gas-liquid disintegrated-flow system depend on the frequencies of the collision between the gas or liquid molecules, which determine the flow configuration of the system (Table 2). The homogeneity and residence time in gaseous mixtures or liquid-gas mixtures depend on the bonding forces that are exerted between fluid segments; these forces improve mixing and, hence, provide a better residence time of the eluent. The flow direction of a fluid or liquid-gas mixtures in a continuous flow system determines the 
flow rate in the same location, and affects that at in same directional distances. The general properties of liquids, such as viscosity, and the flow rates determine the rate of diffusion in the microchannel. This phenomenon has been discussed by Ganan-Calvo et al., who operated a microbubble with a small intercircular area to observe these properties in a liquid-liquid system [105].

Table 2. Applications of microreactors in multiphase systems.

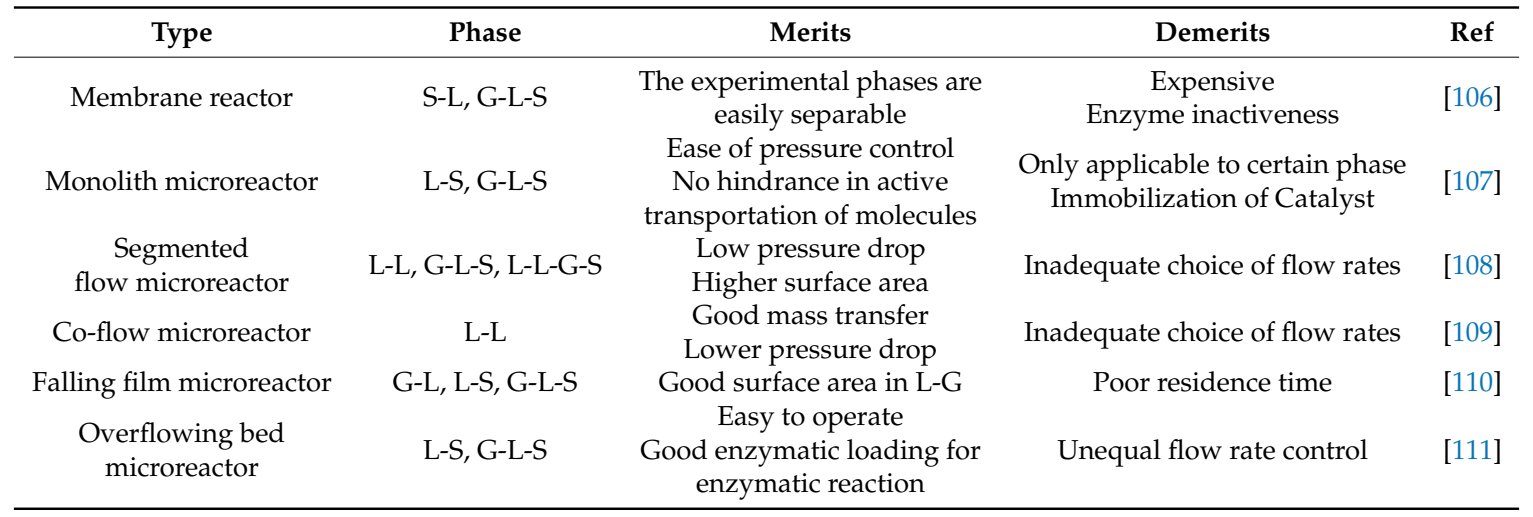

G: gas, L: liquid, S: solid.

Different reaction phases are often easily controlled in a microreactor, even if the reaction is intricate in the mechanism. This type of chemical reaction is generally termed as organic-fluid or liquid in an aqueous medium, and they have zero immiscibility [102,112]. Suryawanshi et al. and Doku et al. have reported other multiple systems, detailing the principles of laminar flow mechanisms in the microchannel during the flow of liquids in small quantities [6,113]. In the microchannel, the mixer regularly provides an improvement by aiding in either diluting or evening out the flow of fluid. The flow pattern is shown in Figure 4a. Due to intermixing, the effects of deletion and diffusion must be considered [114]. If liquids are mixable, the intermolecular diffusional area can stop unwanted chain-reactions $[3,65,115]$. Liquid-liquid systems can maintain a continuous flow, allowing diffusion reactions to happen in crosswise boundaries.

Liquid systems create intersurface tension (especially if immiscible liquids are involved) and, in turn, integration is observed (Figure $4 b$ ) [116,117]. When experiments were conducted in a two-phase liquid-liquid flow at varying flow rates and flow ratios using a water-cyclohexane system, three typical distinct flow regimes were observed, namely, a well-defined slug flow, a drop flow, and a deformed interface flow [118]. In phase-transfer catalysis, liquid-liquid or liquid-liquid-solid phase transfer catalysis are useful tools for synthesizing organic chemicals from immiscible reactants [119]. Phase transfer alkylation in a microreactor was found to proceed smoothly, where the reaction was more efficient than that in a round-bottomed flask with vigorous stirring [120]. The substitution reaction of hexachlorocyclotriphosphazene with phenol to synthesize the partially substituted (phenoxy)chlorocyclotriphasphazene was investigated by using a segment flow reactor in an organic phase/alkaline/catalyst system [121]. The liquid-liquid catalytic phase transfer reaction between benzyl chloride with sodium sulfide has been investigated in a capillary microreactor assisted by ultrasound irradiation [122]. Ahmed-Omer discussed the contact between immiscible liquids in a microfluidic system when creating a segmented flow for biphasic organic chemical reactions, showing significant advantages over conventional flask techniques [123]. For biphasic hydrolysis, the application of various reaction conditions in microreactors using segmented flow can dramatically increase the reaction rate, especially when sonication and phase transfer catalysis are combined with segmentation [123].

Integrated microfluidic devices (called lab-on-a-chip) can offer many advantages, such as deficient volume consumption, inexpensiveness, small-sized, and short sample-to-result time, over traditional analytical devices. Wang et al. discussed the mixing performance in Smale, Baker, and Helical mixers, as shown in Figure 4c [124]. The Baker mixer had better stratification and, hence, better mixing efficiency at low Reynolds numbers than that in the Smale and Helical mixers. However, 
the superiority of mixing efficiency in the Baker mixer faded away with an increase of the Reynolds number, as convective mixing dominates over diffusion mixing at high Reynolds number. Anika et al. reported the rough effect by using a direct numerical simulation based on the lattice Boltzmann method in an irregular wall channel flow initially in a laminar regime and discussed the turbulent characterization [125].

(a)

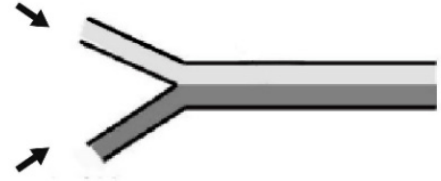

A

(b)

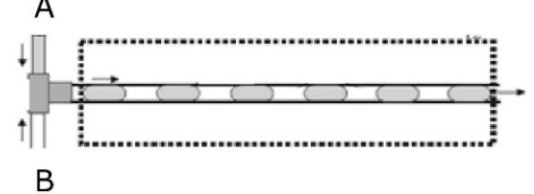

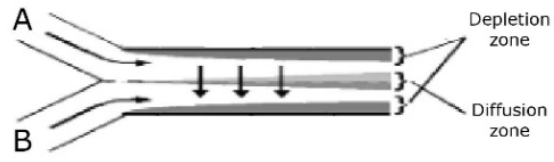

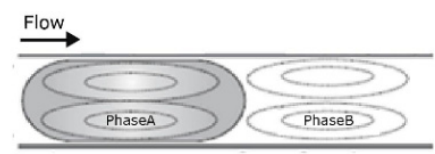

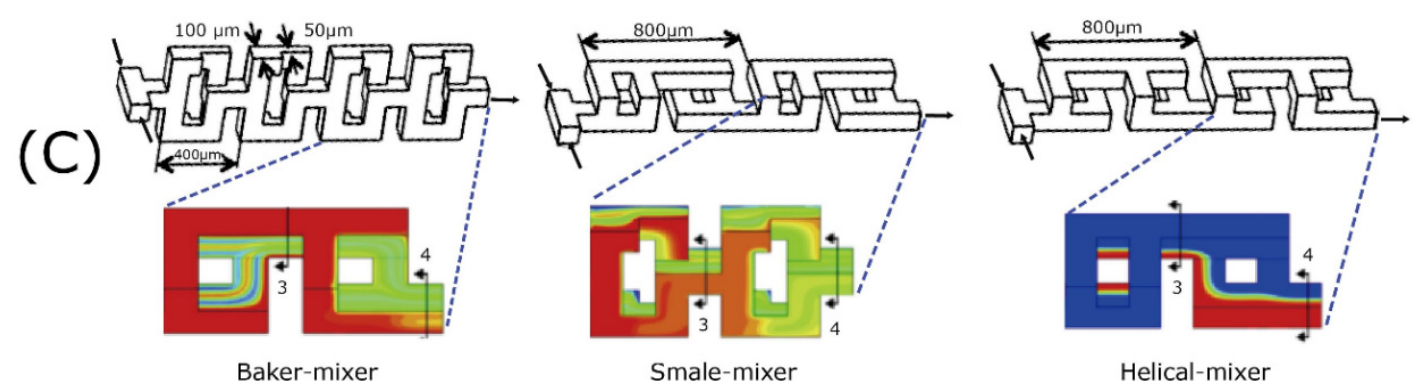

Figure 4. Schematic and flow pattern of microreactor flow systems for (a) laminar flow [114], (b) slug flow [126], and (c) integrated flow [124].

Using modern technology, the analytical simulation of microreactors is typically done using software $[65,66,103,127]$. Software technology can be used to determine the flow rate and the microchannel dimensions of certain specific microreactors for a given chemical or synthetic reaction. Such software has made the job of engineers more accessible and accurate, regarding the scaling of small-scale reactors [72,128]. The advantage of this software industrially is basically to reduce the labor cost and to aid in the mass production of microreactors. If a microreactor model or prototype is assumed, then the software can run analytical stimulations to discern the fabrication details of that specific microreactor. As microreactors normally operate as a continuous flow-system, the momentum balance concerning heat and mass transfer should be considered. Kinetically, the principal and fundamental linear momentum of the phase characteristic can be defined. The simulation of the specifics and the chemical reaction conditions of the microreactor are run by code-based computer software $[73,99,128]$. In the modern world of artificial intelligence (AI), the production of microreactors is becoming more straightforward, as the results and the conversion output of the microreactor can be well-detailed if appropriate parameters are input into the software. Usually, finite element, volume, and part strategies are used as the boundary methodology, which helps to improve the fundamental principles (mathematical prototype) and the linear kinetics (continuous laminar flow) of the microreactor. These methodologies are most well-liked, as they have been supported by significant evidence and can avoid empirical issues. Ferziger et al. and Fletcher et al. described the application of mathematical computer-based code software in detail [7,129].

In the fabrication of microreactors, some specific considerations are followed to achieve a good fabrication design. Schematic fundamental principles are widely followed (i.e., for the finite 
element method and the finite volume method), such as the element in use for the fabrication of the microreactor, which must have a specific chemical characteristic requirements for use with the physical geometric characterization and high facet ratios in the processing of the microreactor [116]. Volume characterization is also vital, as microreactors operate under the laminar flow principle, which means a low Reynolds number is required for the smooth continuous flow of the eluent to be observed. There are some challenges in the creation of microreactors following these schematic principles but, using the finite method (which is generally used) can overcome some of the geometric difficulties inherent to small-scale reactor industries [3,7,130]. In the chemical industry, there exists some software (Fluent, CFD-ACE+, CoventorWare, and COMSOL Multiphysics) for calculating the fundamental mathematical principles of microreactor design. These are used to examine the liquid-fluidic behaviors under different geometries in microreactors. By setting the right parameters, the software can simulate the laminar flow and kinetic characterization of the fluid dynamics, regulating the various prototypes, and generating the results within a reasonable time frame. The microfluidic device is operated in a particular mathematical stimulation principle, which is important as the fluid dynamics and the laminar flow system are essential. Ericson et al. developed a comprehensive report on the software used in the operation of microreactors in fluid flow systems [128]. Work continues in the field of microreactor application, as mass production is always essential in chemical industries [78,90,93]; especially fluidized-bed microreactors [131].

In general, the microreactor types include capillary reactors, plate reactors, and laminar reactors for different applications, as shown in Figure 5a. Microreactors can provide high heat and mass transfer rates for a multiphase system when used as a single channel. For industrial-scale production, the scaling-up of microreactors is essential to achieve throughput in the required range, which is done by the numbering-up of a single channel. Numbering- or scaling-up (i.e., multiple parallel repetitions of microchannel processing units, as shown in Figure $5 b$ was among the significant predictions of microreactor benefits made in pioneering works, later becoming a topic of in-depth industrial analysis on process intensification [132,133]. Numbering-up is also one of the most prominently recognized features in chemical microprocessing. Mendorf et al. reported design and control techniques for the numbering-up of capillary microreactors with uniform multiphase flow distribution [134]. Cherkasov estimated that a throughput of about $10-50 \mathrm{~kg}$ day $^{-1}$ of the liquid product could be achieved in a single reactor at the reaction pressure of 50 bar, based on their results. At the same time, a further increase is expected by numbering-up and process intensification using higher temperatures and pressures, through microwave- or radio-frequency heating [38]. The excellent heat transfer characteristics of microfabricated devices also avoid the risk of potential significant industrial accidents caused by thermal runaway [135]. Model-based scale-up predictions have been presented, including heat and mass balances. The scale-up from microreactors (inner diameter of $0.5 \mathrm{~mm}$ ) to milliscale pilot reactors (inner diameter of $2 \mathrm{~mm}$ ) through increasing the channel diameter and flow rates has been investigated using inline FT-IR spectroscopy [65]. The scale-up of a microreactor with a mixer designed for liquid-liquid reactions has been studied by scaling the hydraulic diameter at increased flow rates and keeping the average rate of energy dissipation constant [16]. As the analytic system or (bio)chemical process is typically complicated-for example, micro-total-analysis-systems ( $\mu$-TAS) or a lab-on-chip (LOC) including pumps, valves, mixers, reactors, and separators-the process must use the network system to produce the target product, as shown in Figure 5c. 
(a)

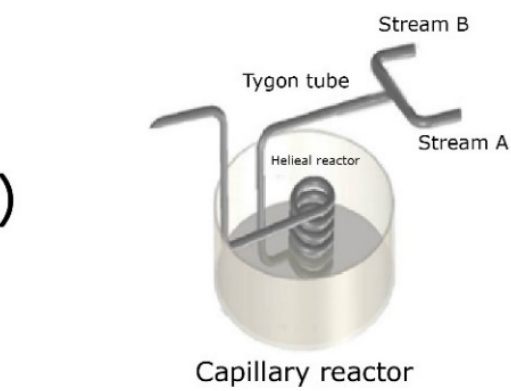

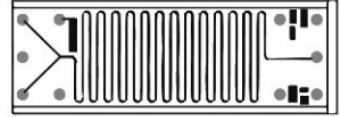

Plate reactor

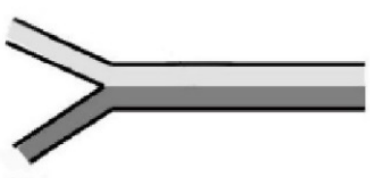

Laminar reactor

(b)

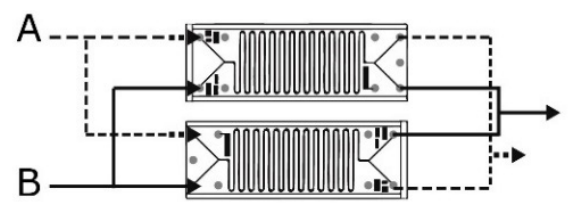

Parallel reactor

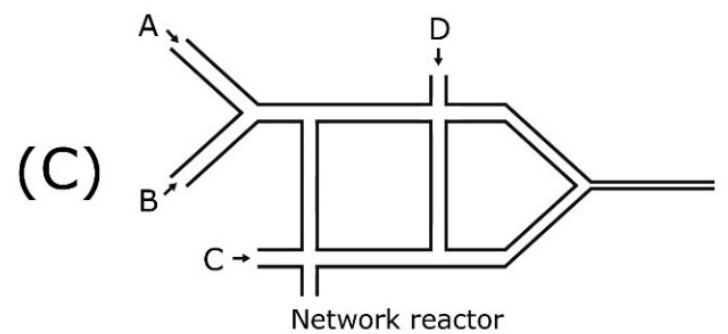

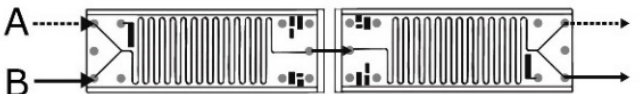

Series reactor

Figure 5. Microreactor types: (a) typical reactor [136], (b) parallel and series reactors [43], and (c) network reactor [43]. Images from Šalić, A.; Tušek, A.; Zelić, B.: Application of microreactors in medicine and biomedicine. Journal of Applied Biomedicine 2012, 10, 137-153.

\section{Innovative Solicitations of Microreactor}

The operations of small-scale reactors are well-known, with the quality of their selectiveness, ease of operation, low use of energy, and most importantly, reduction of pollution by low waste output having been demonstrated. They are also cheaper, compared to other large-scale reactors $[66,116,137]$. The potential for mass transfer in a microreactor is good, where the agitation of a chemical reaction influences its rate of reaction. The structures of these reactors are suitable for small-scale application operations. As microreactors have significant operations industrially, their industrial and laboratory applications have increased significantly. Researchers have discussed the application of microreactor technologies, with reviews highlighting the increasingly detailed application of microreactors and their significance in science and engineering as a whole $[87,138,139]$. Small-scale reactor technology (microreactor) applications are relevant in the following sectors: synthesis of organic chemicals and (bio)polymers, biological and pharmaceutical applications, and synthesis of nanoparticles.

\subsection{Synthesis of Chemical and (Bio)Polymers}

Industrially, small-scale reactors have many vital uses regarding production yield, with various specific application fields. The use of microreactors in industrial chemistry has paved many new ways to synthesize (bio-)organic chemicals and certain medical (pharmaceutical) products $[129,140]$. During the chemical synthesis of these chemicals, certain conditions are of paramount concern for engineers, especially the chemical reaction rate (kinetically), the heat and mass transfer phenomena, and the poisonous nature of certain bio-organic or inorganic compounds. The precaution level is high during the operations of microreactors, due to these specifics of the synthetic chemical processes [141,142]. The general application of small-scale reactors is purposely for industrial production, as their production yield is faster, which makes large-scale production more attainable. As they operate in a laminar continuous flow system, the production of certain organic chemicals 
involves facile synthesis techniques, such as addition reactions to generate cyclo-compounds, as detailed by Nettekoven et al., who demonstrated the chemical synthesis of an organic cyclic compound with a yield higher than $4.98 \mathrm{~g}$ using a small-scale microreactor with commercialized production mechanisms [143]. By utilizing the microreactor to its full potential, they generated a high yield of product (cyclo-compound) with a high conversion rate, demonstrating the effectiveness and efficiency of the microreactor. Small-scale reactors can be amalgamated with the superficial extension of the edges of an irradiated substance, as seen against a dark background. This process is called irradiation, where an electron beam is exposed on the surface of the object, making the edges significant in the chemical synthesis process. This idea has been reported by Aillet et al., who achieved a high production output in a minimal amount of time [144]. They detailed the full transformation of an extremely concentrated liquid mixture within a small radiation period [144]. Individual organic reactions (e.g., esterification reactions) may have complicated reaction rates and, hence, introduce difficulty in deducing their chemical kinetics; however, using a $\mathrm{Y}$-shaped small-scale reactor, this problem could be eliminated.

The synthetic esterification of organic fatty acids can be effectively carried out using microreactors. Surprisingly, a catalyst is not needed in the process, and the rate of selectivity can reach up to 98-99\% at room temperature in a short period. This principle has been demonstrated by Zanati et al. [145]. Some organic chemical reactions, in general, have multiphase, such as liquid-liquid, gas-liquid, or even a solid-medium phase; in these cases, a catalyst may be introduced into the microreactor. The simulation process of a catalyst in a microreactor is convenient and efficient. Glass, as the primary source of the fabrication of a microreactor, is well suited to many-media chemical reactions. Inoue et al. demonstrated this type of reactor with a many-phase system, using palladium as the catalyst at $25^{\circ} \mathrm{C}$ [146]. In some cases, a catalyst is glazed on the walls of the microchannel during the synthesis or fabrication of microreactors. Peroxide has correspondingly been synthesized in this form, with palladium as a catalyst, with the preparation of peroxide being well-documented by Paunovic et al., Freakley et al., and Suryawanshi et al., who discussed the continuous flow mechanisms and the preparation of the catalyst based on the fabrication of the microchannels $[6,147,148]$. Peroxides have been widely synthesized using small-scale reactors; however, they have also been decomposed at high temperatures using sodium as the primary catalyst, which shows that microreactors are versatile regarding chemical reactivity [52]. Small-scale reactors disintegrate the generated heat throughout the chemical feedback (synthesis) more expeditiously than typical batch-reactors, due to the high mass-heat transfer constant [149]. Due to the excellent mass transfer balance in microreactors, dehydrogenation reactions can be completed at steady-state, as suggested by Riano et al., using a rubidium-based catalyst. Pressure drop is usually a concern in a continuous batch reactor system; however, microreactors have shown excellent regulation of pressure, which is why many organic chemical syntheses can be accomplished using small-scale reactors, such as the toluene synthesis, dehydrogenation, and other multiphase complex organic reaction, due to the high-temperature accommodation properties of microreactors [150]. In general, microreactors can achieve temperatures as high as $300{ }^{\circ} \mathrm{C}[151,152]$. Likewise, regulation is set to certainly eliminate side-chain reactions due to high temperatures.

The general application of microreactors can also be extended to polymers, which has been achieved in the form of biomedical devices, cosmetics, and biometers, among others, using polymerization reaction syntheses. Polymers can easily be manufactured using continuous flow high-temperature microreactors. Different shaped microfluidic devices can be used to synthesize polymers for drug delivery, as proposed and demonstrated by Kucuk et al., who formed a solid-based polymer using a V-shaped microreactor [59]. The synthesized polymer could be used to locate drugs, assisting in the study of the pharmacokinetic behaviors of drugs. Ethylene glycol combined with a lactone-cyclic diester has been used as a polymer-based compound in biomedical engineering, which was effective in delivering drugs (in vivo) in patients. The mass production of these polymers is vital, as it aids medical departments in diagnosis. Using 3D continuous flow small-scale reactors, the mass production of ethylene glycol in combination with a nanosubstance has been reported by Min et al., where the geometry 
was well-arranged for the mass production of the polymer [153]. The ideal characteristic of their work was to eliminate any aggregation of the substance, leading to the production of ethylene glycol with its substituent polymer. In a nutshell, Wang et al. designed a microreactor purposely for the production of "Acrylic acid", which is used in nanomedicine; the condition of the chemical synthesis occurred in a gaseous-liquid medium and the reactor were compartmentalized [154]. In any field, the regulation of specific products is necessary, especially in the medical field. Thus, certain microreactors have been built to regulate the production of some polymers used in drug delivery systems; an excellent example of this is the drug PTX (paclitaxel), sold under the name Taxol $[155,156]$. Polymers have high molecular weight, which is vital in knowing some properties of any polymer substance. Polymer materials have many uses in engineering, ranging from chromatographic analysis, resin materials, and making drugs in capsule form. These substances can easily be made using small-scale reactors, as the technology provides mass production and can evenly organize the compositional arrangement. Although polymerization reactions have some free radical side-chain reaction concerns, the production of polymers using microreactors has been increasing. Using the continuous flow mechanisms of small-scale reactors, appropriate residence time can be achieved, thus limiting the formation of free radicals.

Regarding reducing the molecular weight distribution of polymers, Corrigan et al. established a microreactor that utilized a certain chemical reaction (polymerization) mechanism, which eliminated the high molecular weight distribution by using a Zn catalyst, which induced a photoreaction and terminated the free radical propagation stage eventually resulting in the termination stage, hence reducing the molecular weight distribution. The $\mathrm{Zn}$ catalyst assisted in facile chemical reaction synthesis of the monomeric polymer in an open system, and the process occurred in a redox-induced reaction [157]. Polymers can be used in the cleaning of water systems, and polymer-based nanoparticles, paints, and coating-surfaces have been increasingly used in industrial systems over the years. Due to some pollution and health concerns about the emulsions and paints, their commercialization continues to face some challenges. Paclitaxel, as a drug delivery additive, can be synthesized from butyl-acrylate in a continuous laminar flow system small-scale reactor, as reported by Daniloska et al., in which the pressure drop mechanism was well addressed [158]. Their method achieved a high output of product with high functionality of the microreactor. Polymerization reactions usually take time, but in this case, the reactor was correctly optimized with no hindrance, leading to the efficient production of microsubstance structures $[6,86,159]$. The free-radical polymerization of butyl acrylate has been conducted using the numbering-up of capillary microreactors for homogeneous processing [160]. $\mathrm{Su}$ et al. described the engineering principles, such as mass transport phenomena and energy dissipation, related to polymerization processes in microreactors [161].

\subsection{Microreactors for Biological and Pharmaceutical Applications}

Organic (biological) and medicinal uses of microreactors primarily involve biogenesis and organic chemistry progressions, protein evaluation, organic transmission analyses, and systematic evaluation [44,139]. A chemical reaction in a small-scale reactor is usually composed of highly composite mechanisms, which is essential in the pharmaceutical industry, as the production scale must be abundant. A microfluidic biosensor can be made to detect blood sugar and other essential medical parameters. This idea can be used in the chemical industries for the large-scale production of drugs or pharmaceuticals [1,162].

Studies have been carried out on the application of small-scale reactors in the area of basic experimental laboratory analysis; however, some have been focused within the field of medication and biomedicine $[43,44,76]$. The development of small-scale reactors makes manufacturing easier and laboratory analysis more enjoyable. The rate of production is always a concern in the pharmaceutical industry. Thus, the development of more efficient techniques is still required for the upgrading of different chemical syntheses, as well as catabolic and anabolic investigations of organic chemicals and drug pharmacokinetics in drug delivery systems. It is necessary to achieve this determinant in order to 
reduce prices and to meet the demand and supply of the market [75]. In the biomedical field, advanced studies have been carried out to assimilate different analytical processes into single definite entities, which can be achieved using a microreactor and accurate chemical analysis. Specific biological analyses such as cell lysis, detection, and extraction can all be performed by a single microreactor within a short period. The adaptable and scalability of chemical reaction vessels can modernize the medical system and encourage rapid improvements in the health sector. Microreactors have been interestingly used in other fields of biological engineering (e.g., tissue and microengineering) advancement. Tissue engineering is a new field of research, which has paved the way for organ transfer and the induced embedding of devices (in microform) to aid affected organs $[163,164]$.

The biological function of tissue is subordinate in building conventional organs with structural cell density. With the aid of a small microdevice, a cell-tissue skeleton can be made to support a cellular system. As cell-tissues are easily damaged under certain conditions, the body system is exposed. Thus, a microreactor is needed to help generate new cell-tissue to balance the cell propagation, such that the perfect auxiliaries and variations occur. A microreactor could serve as a nutrient delivery agent, as well as removing the unwanted materials in a cycle chain-linkage form [94,95]. Biological small-scale engineering can exploit the benefits of microfluidic technology in all forms, as this equipment has the advantage of working in a laminar flow system, which is also essential in the bloodstream system of the body, and applicable to interaction with individual body cells. It is, therefore, ideal to find a solution that aids in the arrangement and understanding of both the nervous system and somatic cell relocation [5].

Small-scale reactors can perform multiple purposes at once. Microreactors can simulate both the analysis and organization of models at the same time using only one microfluidic reactor with compartmentalized microchannel [165]. In medical laboratories, this kind of reactor can measure the quantification of immune cells, such as CD8+ (cytotoxic) T cells and CD4+ Helper T cells, in a blood sample [165]. Microreactors can also be fabricated using paper, which enables the natural diffusion of liquid in the form of capillaries, which could be a drug delivery-induced substance [166]. Cholestenone is produced from the organic oxidation of cholesterol, and this process can be easily observed in a conceptual microreactor with good channel design, Marques et al. have detailed this effect by fabricating a channel dimensional-system in a microreactor [167]. Esterification reactions are best used in food industries, such as for synthetic grape juice; microreactors can also aid in the synthetic process, as reported by Gumel et al., who manufactured methyl benzoates using a microfluidic device (benzoates derivatives are used as flavoring agents for certain food products) [168]. The use of a lipase enzyme is essential to the catalysis of this reaction. This kind of micro-based reactor can be applied to some biological reaction syntheses. Microfluidic devices can also be used to analyze blood samples, as evidenced by $\mathrm{Wu}$ et al., who made a small, transparent, and elastic poly-urethane microreactor for blood analysis [169]. For general DNA analysis, microreactors are well suited to separation and ligation. Small-scale reactors can be utilized in chemistry-related processes, such as the carbon-carbon bond formation, which is highly useful in the industrial pharmaceutical complex [170].

Generally, biological reactions involve a temperature coordinated mole-to-mole ratio balance between reactants and products. Small scale-reactors are well-defined, regarding heat and mass transfer processes, which makes them suitable for such chemical reactions [171]. The homogeneity of the mixture is always essential in the preparation of nano-based particles, for medical concerns, by determining pharmacokinetic and other vital properties. The concept of homogeneity can be addressed using Si-based microreactors, which have an excellent output production for continuous flow systems [172]. Bolivar et al. documented the application of biocatalysts in small-scale reactors, as reports of chemical synthesis transfiguration have described [173]. Enzymatic reactions are slow processes due to the specificity and selectivity of the active site mechanisms. Thus, this creates a need for a small-scale reactor, which allows easy detection of reaction synthesis [6,173]. 


\subsection{Nanoparticle Synthesis Using Microreactors}

Nanoparticles have been a groundwork focus for over 20 years. The arrival of microreactor technology has provided different means for the production of nano-based particles in small-scale reactors [174]. Recent achievements in the amalgamation of nano-based particles in microreactors have been reported by Zhao et al. [174]. Nano-based particles can be synthesized by continuous flow mechanisms, gaseous-fluidic metameric flow systems, and drop-based small-scale reactors [174]. Variation of nano-based particles can be achieved using micro-liquid chemical synthesis methods (Table 3). Organic or inorganic chemical reactions provide the most effective way to make nano-based particles in large quantities, where a microfluidic device is generally used as the reaction vessel. The reaction characterization occurs during the nucleation and pretreatment processes [6]. The organization and synthetic processes of the nano-based particle have been elaborated $[66,72,100]$. Nano-based particle production denotes those techniques aimed at constructing nanoparticles. Nanoparticles can be derived from bigger particles or fragments, or synthesized using some chemical processes. Amalgamation can be exemplified by structural conjugation to a bioselective substance [12]. The solicitation of nano-based particles in medication is influenced by the tractability to manufacture substances with completely altered shapes, dispersity, biochemical configuration, and magnitude [42]. The production of some nano-based particles, such as $\mathrm{TiO}_{2}$ or metal-silica compounds, among others, is based on a technique involving either continuous flow or segmented- or compartmentalized-flow systems under standard pressure conditions [175]. High pressure is also used in some cases. Generally, in such chemical reaction conditions, most of the nano-based particles are in the aqueous phase. Table 3 gives some details of the production of nanoparticles using different microreactors.

Table 3. Nanoparticle synthesis with different reactor designs.

\begin{tabular}{|c|c|c|c|c|c|}
\hline Reactor Design & Dimension (mm) & Flow Rate $(\mathrm{mL} / \mathrm{min})$ & Nanoparticle & Size (nm) & Refs \\
\hline Capillary Reactor & $\mathrm{D}=0.26, \mathrm{~L}=110-152$ & 0.06 & $\mathrm{PbS} / \mathrm{PbSe}$ & $3-6$ & [176] \\
\hline Y-shaped Capillary & $\mathrm{D}=0.2, \mathrm{~L}=350$ & 0.2 & CdSe-ZnS & 2 & [139] \\
\hline Interdigital Micro mixer & $\mathrm{D}=1.4, \mathrm{~L}=1000$ & 0.5 & $\mathrm{SiO}_{2}$ & 173 & [177] \\
\hline Capillary & $\mathrm{D}=0.74, \mathrm{~L}=1400$ & $0.22-0.84$ & Zeolite & $279-427$ & [178] \\
\hline Y-shaped Microchannel & $\mathrm{D}=0.9, \mathrm{~L}=2200$ & 0.8 & $\mathrm{Cu}_{2} \mathrm{Cr}_{2} \mathrm{O}_{5}$ & $68-265$ & [179] \\
\hline Y-shaped Microchannel & $\mathrm{D}=0.9, \mathrm{~L}=113$ & $3-30$ & $\mathrm{Fe}_{3} \mathrm{O}_{4}$ & $10-23$ & [180] \\
\hline T-shaped Microchannel & - & 7 & $\mathrm{Zn} / \mathrm{Fe}_{3} \mathrm{O}_{4}$ & 4 & {$[4]$} \\
\hline $\begin{array}{l}\text { Y-shaped Microchannel } \\
\text { with tubes } \\
\text { interconnected }\end{array}$ & $\mathrm{D}=0.35, \mathrm{~L}=3.5$ & $2-6$ & $\mathrm{ZnO}$ & 17 & [181] \\
\hline Microchannel & $\mathrm{D}=0.5, \mathrm{~L}=20$ & 64 & $\mathrm{BaSO}_{4}$ & 60 & [182] \\
\hline
\end{tabular}

\subsubsection{Microfluidic Synthesis Schemes of Nanoparticles}

\section{Continuous Flow Microreactors}

The combination of two chemical substances, which eventually results in a chemical reaction, is what forms nano-based particles. Solubility plays a significant part in the production of nanoparticles, as lower solubility favors good precipitation reactions, which, in turn, lead to the synthesis of nanoparticles [59]. Precipitation creates nucleates and proper development. Isolation of product yield is a challenge in the materialization of nanoparticles. As microreactors are a technology that can be processed autonomously, such a synthetic process is well-determined [85]. Micro-based reactors can be divided into continuous flow and segmented- or compartmentalized-flow microreactors. Compartmentalized-flow reactors can be gaseous-liquid and aqueous-aqueous segmented microreactor [142]. Continuous flow microreactor systems have the same operational fundamentals as batch systems. This system is widely used in the microreactor industry due to its uniqueness [167]. Its production output is excellent and, hence, uniformity can be substantially achieved. Diminishing the microchannel permits facile modification of tentative circumstances 
on the order of microseconds, while the feedstock capacity can be significantly condensed to microliter scales $[59,130,150]$. The oxidative methanol reforming reaction has been carried out using $\mathrm{Cu} / \mathrm{ZnO} / \mathrm{Al}_{2} \mathrm{O}_{3} / \mathrm{Cr}_{2} \mathrm{O}_{3} / \mathrm{CeO}_{2}$ with a wash coat by ethylene cellulose (EC) sol on a plate microchannel reactor, as shown in Figure 5a [183].

For droplet-based reactors, the chemical content of the compositional mixtures is different in both chemical reactants, and the solution mixture is not evenly homogenized; this is essential, as reactions with different or multiple pathways lead to different outputs. Commercially, continuous systems lead to high production yield of the synthesized chemical; therefore, they are vital and reasonably applicable industrially, as they lower the cost and reduce the production timeframe. In a continuous flow system, the channels are connected, in an array, in either capillary form or chip-form $[59,85,97]$. Other types of continuous flow microreactors are capillary tube microreactors, coaxial flow microreactors, and 2D micromixing base microreactors. The concept of the capillary tube reactor system can be extended to microfluidic biofuel cells, using enzymes as biocatalysts to oxidize glucose or other biological substances. Table 4 details the nanomaterials used as electrodes in microfluidic biofuel cells, as well as explaining the co-laminar flow systems in the multichannel system array in microreactors. Furthermore, the design geometries of the microfluidic devices are also summarized, which explains the adaptability of the microreactors to different complex chemical reactions.

\section{Gas-Liquid Segmented Microfluidic Microreactors}

Double methods can assist compounding in small-scale reactors. Submissive compounding is primarily used, as it can delineate better, affecting the quality of the microchannel configurations [10]. The contrary method is a vigorous combination, which utilizes splitting to enhance compounding. Both liquid-liquid and gas-liquid interactions in the segmental-flow reactor are used for such determination. Gas-liquid metameric flow reactors are enticing, due to the straightforward separation of the gas from the liquid [9]. Additionally, compared with continuous flow microreactors, they have a good duration residence time distribution (RTD). Therefore, a wide particle size distribution, due to the parabolic speed profiles of segmental flow microreactors, reduces the RTD by finishing reactions in metameric liquid slugs, where segmenting gas is employed to force recirculation, therefore enhancing compounding among the liquid slug [184]. For a continuous flow of reactants without interrupting the transportation of molecules, microfluidic reactors provide good strategies, in the form of gas-liquid segmented flow systems. The segmented flow is produced by wetting part of the chip, which alters the down-flow stream to a partly wetted reaction passage, which helps to detach the liquid lumps. The residence time is directly proportional to the channel dimensions (i.e., length and width) $[73,113,145]$. It is typically established through an experiment that subdivides a reaction; for example, using nitrogen fizzes is operative for the contraction of the element thickness when forming CdSe nanocrystals in capillary tube microreactors. Characterization of gas-liquid microfluidic reactors has led to the reduced size distribution of silicon oxide particles. RTD could be a vital parameter in determining the performance of a gas-liquid metameric reactor, most significantly, for the scale distribution of nanoparticles. Therefore, it is vital to experimentally characterize and/or theoretically predict the RTD $[73,113,145]$. Completely different tracers such as decorated colors, glowing species, or hydrogen ion concentration indicators could also be inserted into the scheme to describe the combination characteristics and ensure appropriate $\operatorname{RTD}[185,186]$. 
Table 4. Nanomaterials used in microreactors.

\begin{tabular}{|c|c|c|c|c|}
\hline Electrolyte & Nanomaterials & Microchannel Scheme (W/H/L) & Electrodeposition & References \\
\hline $\begin{array}{c}\text { Phosphate solvent } \\
0.1 \mathrm{M}\end{array}$ & $\begin{array}{l}\text { Palladium } \\
\text { Palladium or Platinum }\end{array}$ & $\begin{array}{c}\text { Co-laminar flow } \\
\text { T-shaped2.0 mm/0.072-0.173 mm/ } \\
10.2 \mathrm{~mm}\end{array}$ & Bottom-most wall & {$[21,187-189]$} \\
\hline $\mathrm{H}_{2} \mathrm{SO}_{4}$ Solution $0.3 \mathrm{M}$ & $\begin{array}{l}\text { Platinum-black } \\
\text { Platinum-black }\end{array}$ & $\begin{array}{c}\text { Co-laminar flow } \\
\text { Y-shaped } \\
0.54 \text { or } 1.0 \mathrm{~mm} / 0.53 \text { or } \\
1.0 \mathrm{~mm} / 30.2 \mathrm{~mm}\end{array}$ & Side walls & [190-192] \\
\hline $\mathrm{H}_{2} \mathrm{SO}_{4} 0.1 \mathrm{M}$ & Platinum & $\begin{array}{c}\text { Co-laminar flow } \\
\text { F-shaped } \\
0.383 \mathrm{~mm} / 1.0 \mathrm{~mm} / 50.1 \mathrm{~mm}\end{array}$ & $\begin{array}{l}\text { Top-/bottom-most } \\
\text { walls }\end{array}$ & {$[191,193]$} \\
\hline $\begin{array}{c}\mathrm{PBS} \\
\text { and } \mathrm{NaCl}\end{array}$ & $\begin{array}{c}\text { Glucose dehydrogenase } \\
\text { enzymes }\end{array}$ & $\begin{array}{l}\text { Distinct stream } \\
\text { I-shaped }\end{array}$ & Bottom-most wall & {$[191,192,194]$} \\
\hline$(0.1-0.2 \mathrm{M})$ & Platinum & $3.0 \mathrm{~mm}$ wide $/ 1 \mathrm{~mm}$ height & & \\
\hline & & $\begin{array}{l}\text { Distinct stream } \\
\text { I-shape }\end{array}$ & Bottom-most wall & {$[191,195]$} \\
\hline$(0.1-0.2 \mathrm{M})$ & Bilirubin oxidase enzyme & $\begin{array}{c}3.0 \mathrm{~mm} \text { wide } / 0.1-1 \mathrm{~mm} \text { height } \\
\text { Co-laminar flow }\end{array}$ & & \\
\hline $\mathrm{H}_{2} \mathrm{SO}_{4}(2-3 \mathrm{M})$ & - & $\begin{array}{c}\text { Y-shaped } \\
2.0 \mathrm{~mm} / 0.123 \mathrm{~mm} / 27.1 \mathrm{~mm}\end{array}$ & Bottom-most wall & [196] \\
\hline $\begin{array}{l}\mathrm{H}_{2} \mathrm{SO}_{4}(0.3 \mathrm{M}) \text { and } \\
\mathrm{NaOH}(1 \mathrm{M})\end{array}$ & $\begin{array}{l}\text { Platinum } \\
\text { Platinum }\end{array}$ & $\begin{array}{c}\text { Passive electrolyte } \\
0.22 \mathrm{~mm} / 0.07 \mathrm{~mm} / 20 \mathrm{~mm}\end{array}$ & Bottom-most wall & {$[191,197]$} \\
\hline $\mathrm{NaOH}(2.9 \mathrm{M})$ & $\begin{array}{l}\text { Palladium } \\
\text { Gold or Palladium }\end{array}$ & $\begin{array}{l}\text { Co-laminar flow } \\
\text { T-shaped } \\
3.1 \mathrm{~mm} / 0.34 \mathrm{~mm} / 12.2 \mathrm{~mm}\end{array}$ & Bottom-most wall & [187] \\
\hline $\mathrm{H}_{2} \mathrm{SO}_{4}(0.1 \mathrm{M})$ & $\begin{array}{l}\text { Platinum/Ruthenium-black } \\
\text { Platinum-black }\end{array}$ & $\begin{array}{c}\text { Co-laminar flow } \\
\text { F-shaped } \\
1.0 \mathrm{~mm} / 1.0 \mathrm{~mm} / 50 \mathrm{~mm}\end{array}$ & $\begin{array}{l}\text { Top-/bottom-most } \\
\text { walls }\end{array}$ & [198] \\
\hline PBS (pH 7.15) & $\begin{array}{c}\text { Alcohol dehydrogenase } \\
\text { Enzyme } \\
\text { Platinum }\end{array}$ & $\begin{array}{c}\text { Distinct stream } \\
\text { I-shaped } \\
0.2 \mathrm{~mm} / 0.1 \mathrm{~mm} / 25 \mathrm{~mm}\end{array}$ & Bottom-most wall & [199] \\
\hline $\begin{array}{c}\mathrm{H}_{2} \mathrm{SO}_{4}(0.5-0.6 \mathrm{M}) \text { and } \\
\mathrm{KOH}(1-2 \mathrm{M})\end{array}$ & $\begin{array}{l}\text { Platinum /Ruthenium } \\
\text { Platinum }\end{array}$ & $\begin{array}{c}\text { Co-laminar flow } \\
\text { F-shaped } \\
2.0 \mathrm{~mm} / 3.0 \mathrm{~mm} / 22.1 \mathrm{~mm}\end{array}$ & $\begin{array}{l}\text { Top-/bottom-most } \\
\text { walls }\end{array}$ & [200] \\
\hline $\mathrm{H}_{2} \mathrm{SO}_{4}(0.5 \mathrm{M})$ & $\begin{array}{l}\text { Platinum } \\
\text { Platinum }\end{array}$ & $\begin{array}{c}\text { Co-laminar flow } \\
\text { I-shaped } \\
0.5 \mathrm{~mm} / 0.051 \mathrm{~mm} / 20.1 \mathrm{~mm}\end{array}$ & Bottom-most wall & [201] \\
\hline $\mathrm{KOH}(0.2 \mathrm{M})$ & $\begin{array}{l}\text { Nickel hydroxide } \\
\text { Silver oxide }\end{array}$ & $\begin{array}{l}\text { Distinct stream } \\
\text { I-shaped } \\
0.12 \mathrm{~mm} \text { high }\end{array}$ & $\begin{array}{l}\text { Bottom-most wall; } \\
\text { interdigitated }\end{array}$ & [202] \\
\hline $\mathrm{H}_{2} \mathrm{SO}_{4}(0.5-1 \mathrm{M})$ & $\begin{array}{l}\text { Platinum } \\
\text { Platinum }\end{array}$ & $\begin{array}{l}\text { Sequential radial flow } \\
\text { Circular shaped } \\
25.42 \mathrm{~mm} \text { diameter }\end{array}$ & Bottom-most wall & [203] \\
\hline $\begin{array}{c}\mathrm{NaOH}(0.8 \mathrm{M}) \mathrm{H}_{2} \mathrm{SO}_{4} \\
(0.4 \mathrm{M})\end{array}$ & $\begin{array}{l}\text { Platinum } \\
\text { Platinum }\end{array}$ & $\begin{array}{c}\text { Co-laminar flow } \\
\text { H-shaped } \\
1 \mathrm{~mm} / 0.05 \mathrm{~mm} / 10 \mathrm{~mm}\end{array}$ & Bottom-most wall & [204] \\
\hline
\end{tabular}

\subsection{Numerical Models of Microreactors}

The characterization of fluids in microchannels can be categorized in microfluidic devices. Microfluidic technology can be used in different scientific fields, ranging from chemical synthesis and nanoparticle synthesis to biological experimentations or optics technology $[28,205,206]$. Traditionally, as the basic scientific and technological ideas are developed, other complications must be addressed, such as selecting and concentrating on initial applications, developing strategies to comprehend the cycle of improvement, and commercialization. Fluid flow in microscale devices is usually laminar and associated with low Reynolds numbers, where viscous properties control inertial properties, and surface forces are more significant than body forces. In a microfluidic channel, the connection between the fluid velocity and the absolute pressure for an incompressible viscous liquid is given by classical fluid dynamics theory and the well-known Navier-Stokes equation [207]:

$$
\frac{\partial \vec{v}}{\partial t}+(\vec{v} \cdot \vec{\nabla}) \vec{v}=-\vec{\nabla}\left(\frac{P}{\rho}\right)+\mu \Delta \vec{v}
$$


where $v$ denotes the fluid velocity vector, each carried for a set of Euler components $(x, y, z, t), P$ is the absolute pressure, $\rho$ is the relative density, and $\mu$ is the kinematic viscosity [19]. In the instance of a microfluidic horizontally straight channel ( $x$-direction), the flow is continuously laminar under the squat pressure drop most significantly, resulting in a unidirectional flow and a constant total pressure in the cross-section, intended at a fixed pressure drop between the inlet and the outlet of the channel [208-210]. Equation (1) can be streamlined as:

$$
\frac{\partial \vec{v}}{\partial t}=-\frac{1}{\rho}-\frac{\Delta P}{L}+\mu\left(\frac{\partial u^{2}}{\partial y^{2}}+\frac{\partial u^{2}}{\partial z^{2}}\right)
$$

where $L$ denotes the length of the microchannel [211]. When the flow is stretched, the time derivative period is zero $[19,212,213]$. Therefore, Equation (2) can be rewritten and evaluated as:

$$
\frac{-\Delta P}{\eta L}+\frac{\partial u^{2}}{\partial y^{2}}+\frac{\partial u^{2}}{\partial z^{2}}=0,
$$

where $\eta$ is the dynamic viscosity, the product of the dynamic viscosity, and the relative density. Owing to the rectangular cross-section of the microchannel, a 2D technique is often used, which assumes a pseudo-infinite plate flow, except for at the side-wall borders. The directions along the length and height of the microchannel are indicated by the $x$ and $y$ coordinates, respectively. For a dimensionless group, the Reynolds (Re) and Froude (Fr) numbers are considered for the flow system, Peclet number (Pe) for molecular diffusivity, and the Damk"ohler number for the reaction system (Da). In order to facilitate the characterization of flow patterns and extent of interdiffusion in microchannels, $\operatorname{Re}<10$ is required to guarantee microfluidic laminar flow, and $\mathrm{Pe} \approx 10,000$ is required to alleviate the solute crossover [114].

High mixing efficiency, narrow residence time distribution, and nearly isothermal reaction control are preconditions for determining reliable kinetic data. Mixing times should be short compared to the duration of a chemical reaction. Fath et al. reported that the theoretical mixing time $t_{\text {mixing }}$ of intertwined lamellae (including molecular diffusion and shear in a tube in the laminar flow) could be described as a function of the Peclet number [65]:

$$
t_{\text {mixing }}=\frac{\left(\frac{d^{2}}{D_{m}}\right)}{8 P e} \ln (1.52 P e)
$$

where $d$ is the diameter, and $D_{m}$ is the diffusivity. They also showed the dimensions and calculated dimensionless parameters for selected residence times for a lab reactor with pilot millireactors (as empty tubes).

\section{Conclusions}

Microreactors play an essential role in the synthesis of organic chemicals, biopolymers, nanoparticles, and many other substances, in general. The small-sized nature of the microreactor can perform unpredictable chemical reactions with complex pathways and reaction mechanisms. This work presented details of the operations, fundamentals, and structural materials used in the fabrication of small-scale reactors. Their construction/fabrication mechanisms, along with their principal application technologies, were also described, and their commercial significance and mode of chemical production-used for both biological and pharmaceutical purposes-were elaborated. Microreactors can help the medical industry in designing drug delivery systems through effectively synthesizing additives and providing embedded devices. The general substances or materials used in the fabrication of microreactors are also mentioned.

Recently, the technological aspects of small-scale reactors have been gathering an impressive amount of attention in the research world, due to their performance, efficiency, and rapid mass-transfer 
mechanisms. In the future, microreactors may serve to fully replace conventional batch reactors. In contrast to batch reactors, microreactors can synthesize a nanoparticle in a short period. The possibility of integration of different reaction routines within a single reactor is another unique quality of microreactors. However, microreactors still face some challenges, such as commercialization and specific reaction integration problems, which make it difficult for some organic chemical syntheses to be operated in them. Serious investigation of some necessary steps, such as synthesis ability, measurement analysis, extraction, and detection need to be carried out, such that microreactors can be applied widely, throughout all relevant fields of study.

Author Contributions: Writing—original draft preparation, A.A.B.; writing—review and editing, H.-S.W.; supervision, H.-S.W. All authors have read and agreed to the published version of the manuscript.

Funding: We thank for the Ministry of Science and Technology of Taiwan for financially supporting this study under grant number MOST 109-2221-E-155-009.

Conflicts of Interest: The authors do not have any conflict of interest to declare.

\section{References}

1. Yoshida, J.I.; Takahashi, Y.; Nagaki, A. Flash chemistry: Flow chemistry that cannot be done in batch. Chem. Commun. 2013, 49, 9896-9904. [CrossRef]

2. Baraldi, P.T.; Hessel, V. Micro reactor and flow chemistry for industrial applications in drug discovery and development. Green Process. Synth. 2012, 1, 149-167. [CrossRef]

3. Becker, H.; Gärtner, C. Polymer based micro-reactors. Rev. Mol. Biotechnol. 2001, 82, 89-99. [CrossRef]

4. Bothe, D.; Stemich, C.; Warnecke, H.J. Fluid mixing in a T-shaped micro-mixer. Chem. Eng. Sci. 2006, 61, 2950-2958. [CrossRef]

5. Haswell, S.J.; Middleton, R.J.; O'Sullivan, B.; Skelton, V.; Watts, P.; Styring, P. The application of micro reactors to synthetic chemistry. Chem. Commun. 2001, 43, 391-398. [CrossRef]

6. Suryawanshi, P.L.; Gumfekar, S.P.; Bhanvase, B.A.; Sonawane, S.H.; Pimplapure, M.S. A review on microreactors: Reactor fabrication, design, and cutting-edge applications. Chem. Eng. Sci. 2018, 189, 431-448. [CrossRef]

7. Fletcher, P.D.; Haswell, S.J; Pombo-Villar, E.; Warrington, B.H.; Watts, P.; Wong, S.Y.; Zhang, X. Micro reactors: Principles and applications in organic synthesis. Tetrahedron 2002, 58, 4735-4757. [CrossRef]

8. Pennemann, H.; Kolb, G. Review: Microstructured reactors as efficient tool for the operation of selective oxidation reactions. Catal. Today 2016, 278, 3-21. [CrossRef]

9. Plouffe, P.; Roberge, D.M.; Macchi, A. Liquid-liquid flow regimes and mass transfer in various micro-reactors. Chem. Eng. J. 2016, 300, 9-19. [CrossRef]

10. Rizkin, B.A.; Popovic, F.G.; Hartman, R.L. Review article: Spectroscopic microreactors for heterogeneous catalysis. J. Vac. Sci. Technol. A 2019, 37, 050801. [CrossRef]

11. Gavriilidis, A.; Angeli, P.; Cao, E.; Yeong, K.K.; Wan, Y.S.S. Technology and applications of microengineered reactors. Chem. Eng. Res. Design 2002, 80, 3-30. [CrossRef]

12. Haswell, S.J.; Watts, P. Green chemistry: Synthesis in micro reactors. Green Chem. 2003, 5, 240-249. [CrossRef]

13. Kundu, A.; Ahn, J.E.; Park, S.S.; Shul, Y.G.; Han, H.S. Process intensification by micro-channel reactor for steam reforming of methanol. Chem. Eng. J. 2008, 135, 113-119. [CrossRef]

14. He, L.; Fan, Y.; Luo, L.; Bellettre, J.; Yue, J. Preparation of $\mathrm{Pt} / \gamma-\mathrm{Al}_{2} \mathrm{O}_{3}$ catalyst coating in microreactors for catalytic methane combustion. Chem. Eng. J. 2020, 380, 122424. [CrossRef]

15. NÉmethnÉ-SÓVÁGÓ, J.; BENKE, M. Micro-reactors: A new concept for chemical synthesis and technological feasibility. Mater. Sci. Eng. 2014, 39, 89-101.

16. Plouffe, P.; Bittel, M.; Sieber, J.; Roberge, D.M.; Macchi, A. On the scale-up of micro-reactors for liquid-liquid reactions. Chem. Eng. Sci. 2016, 143, 216-225. [CrossRef]

17. Wohlgemuth, R.; Plazl, I.; Žnidaršič-Plazl, P.; Gernaey, K.V.; Woodley, J.M. Microscale technology and biocatalytic processes: Opportunities and challenges for synthesis. Trends Biotechnol. 2015, 33, 302-314. [CrossRef]

18. Wang, X.; Zhu, J.; Bau, H.; Gorte, R.J. Fabrication of micro-reactors using tape-casting methods. Catal. Lett. 2001, 77, 173-177. [CrossRef] 
19. Zebda, A.; Innocent, C.; Renaud, L.; Certin, M.; Pichot, F.; Ferrigno, R.; Tingry, S. Enzyme-Based Microfluidic Biofuel Cell to Generate Micropower in Biofuel's Engineering Process Technology; IntechOpen Limited: London, UK, 2011; p. 564.

20. Kjeang, E.; Sinton, D.; Harrington, D.A. Strategic enzyme patterning for microfluidic biofuel cells. J. Power Sources 2006, 158, 1-12. [CrossRef]

21. Kjeang, E.; Djilali, N.; Sinton, D. Microfluidic fuel cells: A review. J. Power Sources 2009, 186, $353-369$. [CrossRef]

22. Love, J.C.; Anderson, J.R.; Whitesides, G.M. Fabrication of three-dimensional microfluidic systems by soft lithography. Mrs Bulletin 2001, 26, 523-528. [CrossRef]

23. Xia, Y.; Whitesides, G.M. Soft lithography. Annu. Rev. Mater. Sci. 1998, 28, 153-184. [CrossRef]

24. Duffy, D.C.; McDonald, J.C.; Schueller, O.J.A.; Whitesides, G.M. Rapid Prototyping of Microfluidic Systems in Poly(dimethylsiloxane). Anal. Chem. 1998, 70, 4974-4984. [CrossRef] [PubMed]

25. Lee, J.N.; Park, C.; Whitesides, G.M. Solvent compatibility of poly(dimethylsiloxane)-based microfluidic devices. Anal. Chem. 2003, 75, 6544-6554. [CrossRef]

26. Wong, C.M.; Wong, K.H.; Chen, X.D. Glucose oxidase: Natural occurrence, function, properties and industrial applications. Appl. Microbiol. Biotechnol. 2008, 78, 927-938. [CrossRef]

27. Turkenburg, D.H.; Fischer, H.R. Diels-Alder based, thermo-reversible cross-linked epoxies for use in self-healing composites. Polymer 2015, 79, 187-194. [CrossRef]

28. Shukla, A.K.; Raman, R.K.; Scott, K. Advances in mixed-reactant fuel cells. Fuel Cells 2005, 5, $436-447$. [CrossRef]

29. Bullen, R.A.; Arnot, T.C.; Lakeman, J.B.; Walsh, F.C. Biofuel cells and their development. Biosens. Bioelectron. 2006, 21, 2015-2045. [CrossRef]

30. Volpatti, L.R.; Yetisen, A.K. Commercialization of microfluidic devices. Trends Biotechnol. 2014, 32, 347-350. [CrossRef]

31. Krishna, K.S.; Li, Y.; Li, S.; Kumar, C.S.S.R. Lab-on-a-chip synthesis of inorganic nanomaterials and quantum dots for biomedical applications. Adv. Drug Deliv. Rev. 2013, 65, 1470-1495. [CrossRef]

32. Phillips, T.W.; Lignos, I.G.; Maceiczyk, R.M.; deMello, A.J.; deMello, J.C. Nanocrystal synthesis in microfluidic reactors: Where next? Lab Chip 2014, 14, 3172-3180. [CrossRef] [PubMed]

33. Jolliffe, H.G.; Gerogiorgis, D.I. Process modelling and simulation for continuous pharmaceutical manufacturing of ibuprofen. Chem. Eng. Res. Design 2015, 97, 175-191. [CrossRef]

34. Rossetti, I.; Compagnoni, M. Chemical reaction engineering, process design and scale-up issues at the frontier of synthesis: Flow chemistry. Chem. Eng. J. 2016, 296, 56-70. [CrossRef]

35. Lo, I.C.; Wu, H.S. Methanol formation from carbon dioxide hydrogenation using $\mathrm{Cu} / \mathrm{ZnO} / \mathrm{Al}_{2} \mathrm{O}_{3}$ catalyst. J. Taiwan Inst. Chem. Eng. 2019, 98, 124-131. [CrossRef]

36. Yang, T.; Zhang, G.; Zhang, Q.; Liu, B.; Zhang, L. Magnesium modified mesh-type $\mathrm{Cu} / \gamma-\mathrm{Al}_{2} \mathrm{O}_{3} / \mathrm{Al}$ catalysts: Low acid density catalysts for methanol steam reforming. Catal. Lett. 2020. [CrossRef]

37. Yen, B.K.H.; Stott, N.E.; Jensen, K.F.; Bawendi, M.G. A continuous-flow microcapillary reactor for the preparation of a size series of CdSe nanocrystals. Adv. Mater. 2003, 15, 1858-1862. [CrossRef]

38. Cherkasov, N.; Al-Rawashdeh, M.m.; Ibhadon, A.O.; Rebrov, E.V. Scale up study of capillary microreactors in solvent-free semihydrogenation of 2-methyl-3-butyn-2-ol. Catal. Today 2016, 273, 205-212. [CrossRef]

39. Fitzpatrick, D.E.; Ley, S.V. Engineering chemistry: Integrating batch and flow reactions on a single, automated reactor platform. React. Chem. Eng. 2016, 1, 629-635. [CrossRef]

40. Jensen, K.F.; Reizman, B.J.; Newman, S.G. Tools for chemical synthesis in microsystems. Lab Chip 2014, 14, 3206-3212. [CrossRef]

41. Kralj, J.G.; Sahoo, H.R.; Jensen, K.F. Integrated continuous microfluidic liquid-liquid extraction. Lab Chip 2007, 7, 256-263. [CrossRef]

42. Honda, T.; Miyazaki, M.; Yamaguchi, Y.; Nakamura, H.; Maeda, H. Integrated microreaction system for optical resolution of racemic amino acids. Lab Chip 2007, 7, 366-372. [CrossRef] [PubMed]

43. Šalić, A.; Tušek, A.; Zelić, B. Application of microreactors in medicine and biomedicine. J. Appl. Biomed. 2012, 10, 137-153. [CrossRef]

44. Yao, X.; Zhang, Y.; Du, L.; Liu, J.; Yao, J. Review of the applications of microreactors. Renew. Sustain. Energy Rev. 2015, 47, 519-539. [CrossRef] 
45. Yue, J. Multiphase flow processing in microreactors combined with heterogeneous catalysis for efficient and sustainable chemical synthesis. Catal. Today 2018, 308, 3-19. [CrossRef]

46. Urban, S.; Kieninger, J.; Deschner, B.J.; Kraut, M.; Dittmeyer, R.; Urban, G.A.; Weltin, A. Multiparametric, spatially resolved detection of $\mathrm{H}_{2} \mathrm{O}_{2}$ and $\mathrm{O}_{2}$ with electrochemical microsensor array in synthesis membrane microreactors. In Proceedings of the 2019 20th International Conference on Solid-State Sensors, Actuators and Microsystems \& Eurosensors XXXIII (TRANSDUCERS \& EUROSENSORS XXXIII), Berlin/Heidelbrg, Germany, 23-27 June 2019; pp. 1297-1300.

47. Chucherd, N.; Pavarajarn, V. Reactive extraction of metal ion and simultaneous stripping of nanofibers-supported liquid membrane in a microchannel. In Proceedings of the 2019 Pure and Applied Chemistry International Conference, Flic-en-Flac, Mauritius, 6-10 July 2020.

48. Jensen, K.F. Flow chemistry-Microreaction technology comes of age. AIChE J. 2017, 63, 858-869. [CrossRef]

49. Liu, D.-M.; Chen, J.; Shi, Y.-P. An online immobilized $\alpha$-glucosidase microreactor for enzyme kinetics and inhibition assays. RSC Adv. 2015, 5, 56841-56847. [CrossRef]

50. Martínez-Cisneros, C.S.; Pedro, S.G.-d.; Puyol, M.; García-García, J.; Alonso-Chamarro, J. Design, fabrication and characterization of microreactors for high temperature syntheses. Chem. Eng. J. 2012, 211-212, 432-441. [CrossRef]

51. Ren, W.; Perumal, J.; Wang, J.; Wang, H.; Sharma, S.; Kim, D.-P. Whole ceramic-like microreactors from inorganic polymers for high temperature or/and high pressure chemical syntheses. Lab Chip 2014, 14, 779-786. [CrossRef]

52. Shang, M.; Noël, T.; Su, Y.; Hessel, V. Kinetic study of hydrogen peroxide decomposition at high temperatures and concentrations in two capillary microreactors. AIChE J. 2017, 63, 689-697. [CrossRef]

53. Saksena, P.; Tadigadapa, S.; Yetter, R.A. Design, fabrication and analysis of stagnation flow microreactors used to study hypergolic reactions. Lab Chip 2015, 15, 2248-2257. [CrossRef]

54. Floyd, T.M.; Losey, M.W.; Firebaugh, S.L.; Jensen, K.F.; Schmidt, M.A. Novel liquid phase microreactors for safe production of hazardous specialty chemicals. In Microreaction technology: Industrial Prospects; Springer: Berlin/Heidelberg, Germany, 2000; pp. 171-180.

55. Srinivasan, R.; Hsing, I.-M.; Berger, P.E.; Jensen, K.F.; Firebaugh, S.L.; Schmidt, M.A.; Harold, M.P.; Lerou, J.J.; Ryley, J.F. Micromachined reactors for catalytic partial oxidation reactions. AIChE J. 1997, 43, 3059-3069. [CrossRef]

56. Azouz, A.B.; Murphy, S.; Karazi, S.; Vázquez, M.; Brabazon, D. Fast fabrication process of microfluidic devices based on cyclic olefin copolymer. Mater. Manuf. Processes 2014, 29, 93-99. [CrossRef]

57. Fouillet, Y.; Parent, C.; Gropplero, G.; Davoust, L.; Achard, J.L.; Revol-Cavalier, F.; Verplanck, N. Stretchable material for microfluidic applications. Proceedings 2017, 1, 501. [CrossRef]

58. Halldorsson, S.; Lucumi, E.; Gómez-Sjöberg, R.; Fleming, R.M.T. Advantages and challenges of microfluidic cell culture in polydimethylsiloxane devices. Biosens. Bioelectron. 2015, 63, 218-231. [CrossRef]

59. Kucuk, I.; Edirisinghe, M. Microfluidic preparation of polymer nanospheres. J. Nanoparticle Res. 2014, 16, 2626. [CrossRef]

60. Zilio, C.; Sola, L.; Damin, F.; Faggioni, L.; Chiari, M. Universal hydrophilic coating of thermoplastic polymers currently used in microfluidics. Biomed. Microdevices 2014, 16, 107-114. [CrossRef]

61. Shah, K.; Shin, W.C.; Besser, R.S. Novel microfabrication approaches for directly patterning PEM fuel cell membranes. J. Power Sources 2003, 123, 172-181. [CrossRef]

62. Hunter, R.J. Zeta Potential in Colloid Science: Principles and Applications; Academic Press: Cambridge, MA, USA, 2013; Volume 2.

63. Tiggelaar, R.M.; Benito-López, F.; Hermes, D.C.; Rathgen, H.; Egberink, R.J.M.; Mugele, F.G.; Reinhoudt, D.N.; van den Berg, A.; Verboom, W.; Gardeniers, H.J.G.E. Fabrication, mechanical testing and application of high-pressure glass microreactor chips. Chem. Eng. J. 2007, 131, 163-170. [CrossRef]

64. Zhang, L.; Leng, C.; Du, G. Polyvinyl alcohol/fulvic acid composite adsorbent gel prepared by microreactor. Earth Environ. Sci. 2019, 300, 052006. [CrossRef]

65. Fath, V.; Szmais, S.; Lau, P.; Kockmann, N.; Röder, T. Model-based scale-up predictions: From micro to millireactors using inline FT-IR spectroscopy. Org. Process Res. Dev. 2019, 23, 2020-2030. [CrossRef]

66. Fletcher, P.D.; Haswell, S.J.; Zhang, X. Electrical currents and liquid flow rates in micro-reactors. Lab Chip 2001, 1, 115-121. [CrossRef] 
67. Hessel, V. From microreactor design to microreactor process design. Chem. Eng. Technol. 2005, $28,243$. [CrossRef]

68. Vican, J.; Gajdeczko, B.F.; Dryer, F.L.; Milius, D.L.; Aksay, I.A.; Yetter, R.A. Development of a microreactor as a thermal source for microelectromechanical systems power generation. Proc. Combust. Inst. 2002, 29, 909-916. [CrossRef]

69. Sharada, S.; Suryawanshi, P.L.; Kumar, P.R.; Gumfekar, S.P.; Narsaiah, T.B.; Sonawane, S.H. Synthesis of palladium nanoparticles using continuous flow microreactor. Colloids Surf. A 2016, 498, 297-304. [CrossRef]

70. Sun, L.; Luan, W.; Shan, Y.; Tu, S.-T. One-step synthesis of monodisperse Au-Ag alloy nanoparticles in a microreaction system. Chem. Eng. J. 2012, 189, 451-455. [CrossRef]

71. Tsao, C.-W. Polymer microfluidics: Simple, low-cost fabrication process bridging academic lab research to commercialized production. Micromachines 2016, 7, 225. [CrossRef]

72. Friend, J.; Yeo, L. Fabrication of microfluidic devices using polydimethylsiloxane. Biomicrofluidics 2010, 4, 026502. [CrossRef]

73. Eddings, M.A.; Johnson, M.A.; Gale, B.K. Determining the optimal PDMS-PDMS bonding technique for microfluidic devices. J. Micromechanics Microengineering 2008, 18, 067001. [CrossRef]

74. Chong, Z.Z.; Tor, S.B.; Loh, N.H.; Wong, T.N.; Gañán-Calvo, A.M.; Tan, S.H.; Nguyen, N.-T. Acoustofluidic control of bubble size in microfluidic flow-focusing configuration. Lab Chip 2015, 15, 996-999. [CrossRef]

75. Tan, S.H.; Nguyen, N.T.; Chua, Y.C.; Kang, T.G. Oxygen plasma treatment for reducing hydrophobicity of a sealed polydimethylsiloxane microchannel. Biomicrofluidics 2010, 4, 032204. [CrossRef]

76. Yoon, T.-H.; Park, S.-H.; Min, K.-I.; Zhang, X.; Haswell, S.; Kim, D. Novel inorganic polymer derived microreactors for organic microchemistry applications. Lab Chip 2008, 8, 1454-1459. [CrossRef]

77. West, J.; Karamata, B.; Lillis, B.; Gleeson, J.; Alderman, J.; Collins, J.; Lane, B.; Mathewson, A.; Berney, H. Application of magnetohydrodynamic actuation to continuous flow chemistry. Lab Chip 2002, 2, 224-230. [CrossRef]

78. Mills, P.L.; Nicole, J.F. Multiple automated reactor systems (MARS). 2. effect of microreactor configurations on homogeneous gas-phase and wall-catalyzed reactions for 1,3-butadiene oxidation. Ind. Eng. Chem. Res. 2005, 44, 6453-6465. [CrossRef]

79. Watts, P.; Haswell, S.J. The application of micro reactors for organic synthesis. Chem. Soc. Rev. 2005, 34, 235-246. [CrossRef]

80. Tiwari, A.; Rajesh, V.M.; Yadav, S. Biodiesel production in micro-reactors: A review. Energy Sustain. Dev. 2018, 43, 143-161. [CrossRef]

81. Knitter, R.; Göhring, D.; Risthaus, P.; Haußelt, J. Microfabrication of ceramic microreactors. Microsyst. Technol. 2001, 7, 85-90. [CrossRef]

82. Acikgoz, C.; Hempenius, M.A.; Huskens, J.; Vancso, G.J. Polymers in conventional and alternative lithography for the fabrication of nanostructures. Eur. Polym. J. 2011, 47, 2033-2052. [CrossRef]

83. Jena, R.K.; Yue, C.Y. Cyclic olefin copolymer based microfluidic devices for biochip applications: Ultraviolet surface grafting using 2-methacryloyloxyethyl phosphorylcholine. Biomicrofluidics 2012, 6, 012822. [CrossRef]

84. Konstantinou, D.; Shirazi, A.; Sadri, A.; Young, E.W.K. Combined hot embossing and milling for medium volume production of thermoplastic microfluidic devices. Sens. Actuators B 2016, 234, 209-221. [CrossRef]

85. Pattekar, A.V.; Kothare, M.V. A microreactor for hydrogen production in micro fuel cell applications. J. Microelectromech. Syst. 2004, 13, 7-18. [CrossRef]

86. Plouffe, P. Micro-Reactor Design for Fast Liquid Liquid Reactions. Ph.D. Thesis, University of Ottawa, Ottawa, ON, Canada, 2015.

87. Urban, P.L.; Goodall, D.M.; Bruce, N.C. Enzymatic microreactors in chemical analysis and kinetic studies. Biotechnol. Adv. 2006, 24, 42-57. [CrossRef] [PubMed]

88. Waterkamp, D.A.; Heiland, M.; Schlüter, M.; Sauvageau, J.C.; Beyersdorff, T.; Thöming, J. Synthesis of ionic liquids in micro-reactors-A process intensification study. Green Chem. 2007, 9, 1084-1090. [CrossRef]

89. Cheemalapati, S.; Ladanov, M.; Winskas, J.; Pyayt, A. Optimization of dry etching parameters for fabrication of polysilicon waveguides with smooth sidewall using a capacitively coupled plasma reactor. Appl. Opt. 2014, 53, 5745-5749. [CrossRef] [PubMed]

90. Miyawaki, Y.; Kondo, Y.; Sekine, M.; Ishikawa, K.; Hayashi, T.; Takeda, K.; Kondo, H.; Yamazaki, A.; Ito, A.; Matsumoto, H.; et al. Highly Selective Etching of SiO2over Si3N4and Si in Capacitively Coupled Plasma Employing C5HF7Gas. Jpn. J. Appl. Phys. 2013, 52, 016201. [CrossRef] 
91. Guckenberger, D.J.; de Groot, T.E.; Wan, A.M.D.; Beebe, D.J.; Young, E.W.K. Micromilling: A method for ultra-rapid prototyping of plastic microfluidic devices. Lab Chip 2015, 15, 2364-2378. [CrossRef]

92. Roberge, D. Lonza-Hazardous flow chemistry for streamlined large scale synthesis. Green Process. Synth. 2012, 1, 129. [CrossRef]

93. Pileni, M.P. Reverse micelles as microreactors. J. Phys. Chem. 1993, 97, 6961-6973. [CrossRef]

94. Zeng, D.; Pan, M.; Wang, L.; Tang, Y. Fabrication and characteristics of cube-post microreactors for methanol steam reforming. Appl. Energy 2012, 91, 208-213. [CrossRef]

95. Zhang, B.; Chen, Z. Screening of cathepsin B inhibitors in traditional Chinese medicine by capillary electrophoresis with immobilized enzyme microreactor. J. Pharm. Biomed. Anal. 2019, 176, 112811. [CrossRef]

96. Li, Y.; Yan, L.; Liu, Y.; Qian, K.; Liu, B.; Yang, P.; Liu, B. High-efficiency nano/micro-reactors for protein analysis. RSC Adv. 2015, 5, 1331-1342. [CrossRef]

97. Muhler, M.; Schlögl, R.; Eder, S.; Ertl, G. Design of a continuous flow microreactor attached to a surface analysis system: First results with an iron oxide based catalyst. Surf. Sci. 1987, 189-190, 69-79. [CrossRef]

98. Kolb, G. Review: Microstructured reactors for distributed and renewable production of fuels and electrical energy. Chem. Eng. Process. Process Intensif. 2013, 65, 1-44. [CrossRef]

99. Effenhauser, C.S.; Bruin, G.J.M.; Paulus, A.; Ehrat, M. Integrated capillary electrophoresis on flexible silicone microdevices: Analysis of dna restriction fragments and detection of single DNA molecules on microchips. Anal. Chem. 1997, 69, 3451-3457. [CrossRef] [PubMed]

100. Gambhire, S.; Patel, N.; Gambhire, G.; Kale, S. A Review on different micromixers and its micromixing within microchannel. Int. J. Curr. Eng. Technol. 2016, 4, 409-413.

101. Ober, T.J.; Foresti, D.; Lewis, J.A. Active mixing of complex fluids at the microscale. Proc. Natl. Acad. Sci. USA 2015, 112, 12293-12298. [CrossRef] [PubMed]

102. Jovanović, J.; Rebrov, E.V.; Nijhuis, T.A.; Kreutzer, M.T.; Hessel, V.; Schouten, J.C. Liquid-liquid flow in a capillary microreactor: Hydrodynamic flow patterns and extraction performance. Ind. Eng. Chem. Res. 2012, 51, 1015-1026. [CrossRef]

103. Farshchian, B.; Amirsadeghi, A.; Choi, J.; Park, D.S.; Kim, N.; Park, S. 3D nanomolding and fluid mixing in micromixers with micro-patterned microchannel walls. Nano Converg. 2017, 4, 1-10. [CrossRef]

104. Yue, J.; Falke, F.H.; Schouten, J.C.; Nijhuis, T.A. Microreactors with integrated UV/Vis spectroscopic detection for online process analysis under segmented flow. Lab Chip 2013, 13, 4855-4863. [CrossRef]

105. Gañán-Calvo, A.M.; Gordillo, J.M. Perfectly monodisperse microbubbling by capillary flow focusing. Phys. Rev. Lett. 2001, 87, 274501. [CrossRef]

106. Machsun, A.L.; Gozan, M.; Nasikin, M.; Setyahadi, S.; Yoo, Y.J. Membrane microreactor in biocatalytic transesterification of triolein for biodiesel production. Biotechnol. Bioprocess Eng. 2010, 15, 911-916. [CrossRef]

107. Zhao, W.-W.; Wang, J.; Xu, J.-J.; Chen, H.-Y. Energy transfer between CdS quantum dots and Au nanoparticles in photoelectrochemical detection. Chem. Commun. 2011, 47, 10990-10992. [CrossRef] [PubMed]

108. Karande, R.; Schmid, A.; Buehler, K. Miniaturizing biocatalysis: Enzyme-catalyzed reactions in an aqueous/organic segmented flow capillary microreactor. Adv. Synth. Catal. 2011, 353, 2511-2521. [CrossRef]

109. Marques, P.; Gonçalves, G.; Cruz, S.; Almeida, N.; Singh, M.; Grácio, J.; Sousa, A. Functionalized graphene nanocomposites. Adv. Nanocomposite Technol. 2011, 11, 247-272.

110. Vankayala, B.K.; Löb, P.; Hessel, V.; Menges, G.; Hofmann, C.; Metzke, D.; Krtschil, U.; Kost, H.-J. Scale-up of process intensifying falling film microreactors to pilot production scale. Int. J. Chem. React. Eng. 2007, 5, 1542-6580. [CrossRef]

111. Fu, H.; Dencic, I.; Tibhe, J.; Pedraza, C.S.; Wang, Q.; Noel, T.; Meuldijk, J.; de Croon, M.; Hessel, V.; Weizenmann, N. Threonine aldolase immobilization on different supports for engineering of productive, cost-efficient enzymatic microreactors. Chem. Eng. J. 2012, 207, 564-576. [CrossRef]

112. Woitalka, A.; Kuhn, S.; Jensen, K.F. Scalability of mass transfer in liquid-liquid flow. Chem. Eng. Sci. 2014, 116, 1-8. [CrossRef]

113. Doku, G.N.; Verboom, W.; Reinhoudt, D.N.; van den Berg, A. Microbubble beam (MBB), a potential dispersion mechanism for multiphase gas-liquid microreactor systems. Ind. Eng. Chem. Res. 2003, 42, 3721-3730. [CrossRef]

114. Choban, E.R.; Markoski, L.J.; Wieckowski, A.; Kenis, P.J.A. Microfluidic fuel cell based on laminar flow. J. Power Sources 2004, 128, 54-60. [CrossRef] 
115. Bonura, G.; Cannilla, C.; Frusteri, L.; Catizzone, E.; Todaro, S.; Migliori, M.; Giordano, G.; Frusteri, F. Interaction effects between $\mathrm{CuO}-\mathrm{ZnO}-\mathrm{ZrO} 2$ methanol phase and zeolite surface affecting stability of hybrid systems during one-step CO2 hydrogenation to DME. Catal. Today 2019, 345, 175-182. [CrossRef]

116. Cabeza, V.S. High and efficient production of nanomaterials by microfluidic reactor approaches. In Advances in Microfluidics-New Applications in Biology, Energy, and Materials Sciences; InTech Rijeka: Rijeka, Croatia, 2016.

117. Kashid, M.N.; Harshe, Y.M.; Agar, D.W. Liquid-liquid slug flow in a capillary: An alternative to suspended drop or film contactors. Ind. Eng. Chem. Res. 2007, 46, 8420-8430. [CrossRef]

118. Kashid, M.N.; Gupta, A.; Renken, A.; Kiwi-Minsker, L. Numbering-up and mass transfer studies of liquid-liquid two-phase microstructured reactors. Chem. Eng. J. 2010, 158, 233-240. [CrossRef]

119. Yang, H.M.; Wu, H.S. Interfacial mechanism and kinetics of phase-transfer catalysis. Catal. Rev. 2003, 45, 463-540. [CrossRef]

120. Ueno, M.; Hisamoto, H.; Kitamori, T.; Kobayashi, S. Phase-transfer alkylation reactions using microreactors. Chem. Commun. 2003, 10, 936-937. [CrossRef] [PubMed]

121. Wu, H.S.; Wang, C.S. Liquid-solid-liquid phase-transfer catalysis in sequential phosphazene reaction: Kinetic investigation and reactor design. Chem. Eng. Sci. 2003, 58, 3523-3534. [CrossRef]

122. Aljbour, S.; Yamada, H.; Tagawa, T. Ultrasound-assisted phase transfer catalysis in a capillary microreactor. Chem. Eng. Process. Process Intensif. 2009, 48, 1167-1172. [CrossRef]

123. Ahmed-Omer, B.; Barrow, D.; Wirth, T. Effect of segmented fluid flow, sonication and phase transfer catalysis on biphasic reactions in capillary microreactors. Chem. Eng. J. 2008, 135, S280-S283. [CrossRef]

124. Ruijin, W.; Beiqi, L.; Dongdong, S.; Zefei, Z. Investigation on the splitting-merging passive micromixer based on Baker's transformation. Sensors Actuators B Chem. 2017, 249, 395-404. [CrossRef]

125. Anika, N.N.; Djenidi, L.; Tardu, S. Roughness effect in an initially laminar channel flow. J. Fluid Mech. 2020, 892. [CrossRef]

126. Karande, R. Development and Application of Microreactors for Biocatalytic Reactions. Ph.D. Thesis, Technische Universität Dortmund Fakultät Bio- und Chemieingenieurwesen, Dortmund, Germany, 2014. Available online: http://129.217.131.68:8080/bitstream/2003/33133/2/Summary.pdf (accessed on 25 July 2020).

127. Fletcher, P.D.I.; Haswell, S.J.; Paunov, V.N. Theoretical considerations of chemical reactions in micro-reactors operating under electroosmotic and electrophoretic control. Analyst 1999, 124, 1273-1282. [CrossRef]

128. Erickson, D. Towards numerical prototyping of labs-on-chip: Modeling for integrated microfluidic devices. Microfluid. Nanofluidics 2005, 1, 301-318. [CrossRef]

129. Ferziger, J.H.; Perić, M.; Street, R.L. Computational Methods for Fluid Dynamics; Springer: Berlin/Heidelberg, Germany, 2002; Volume 3.

130. Liao, Y.S.; Chen, Y.T. Precision fabrication of an arrayed micro metal probe by the laser-LIGA process. J. Micromech. Microeng. 2005, 15, 2433-2440. [CrossRef]

131. Potic, B.; Kersten, S.R.A.; Ye, M.; van der Hoef, M.A.; Kuipers, J.A.M.; van Swaaij, W.P.M. Fluidization with hot compressed water in micro-reactors. Chem. Eng. Sci. 2005, 60, 5982-5990. [CrossRef]

132. Schenk, R.; Hessel, V.; Hofmann, C.; Kiss, J.; Löwe, H.; Ziogas, A. Numbering-up of micro devices: A first liquid-flow splitting unit. Chem. Eng. J. 2004, 101, 421-429. [CrossRef]

133. Jensen, K.F. Microreaction engineering-Is small better? Chem. Eng. Sci. 2001, 56, 293-303. [CrossRef]

134. Mendorf, M.; Nachtrodt, H.; Mescher, A.; Ghaini, A.; Agar, D.W. Design and control techniques for the numbering-up of capillary microreactors with uniform multiphase flow distribution. Ind. Eng. Chem. Res. 2010, 49, 10908-10916. [CrossRef]

135. Chován, T.; Guttman, A. Microfabricated devices in biotechnology and biochemical processing. Trends Biotechnol. 2002, 20, 116-122. [CrossRef]

136. Choi, C.H.; Su, Y.W.; Chang, C.H. Effects of fluid flow on the growth and assembly of ZnO nanocrystals in a continuous flow microreactor. CrystEngComm 2013, 15, 3326-3333. [CrossRef]

137. Brandner, j.J. Fabrication of microreactors made from metals and ceramics. In Microreactors in Organic Synthesis and Catalysis; Wiley Online Library: Hoboken, NJ, USA, 2008; pp. 1-7.

138. Wagner, J.; Kirner, T.; Mayer, G.; Albert, J.; Köhler, J.M. Generation of metal nanoparticles in a microchannel reactor. Chem. Eng. J. 2004, 101, 251-260. [CrossRef]

139. Wang, S.; Su, P.; Yang, Y. Online immobilized enzyme microreactor for the glucose oxidase enzymolysis and enzyme inhibition assay. Anal. Biochem. 2012, 427, 139-143. [CrossRef] 
140. Junkers, T. Precision polymer design in microstructured flow reactors: Improved control and first upscale at once. Macromol. Chem. Phys. 2017, 218, 1600421. [CrossRef]

141. Cantillo, D.; Kappe, C.O. Halogenation of organic compounds using continuous flow and microreactor technology. React. Chem. Eng. 2017, 2, 7-19. [CrossRef]

142. Movsisyan, M.; Delbeke, E.; Berton, J.; Battilocchio, C.; Ley, S.; Stevens, C. Taming hazardous chemistry by continuous flow technology. Chem. Soc. Rev. 2016, 45, 4892-4928. [CrossRef] [PubMed]

143. Nettekoven, M.; Püllmann, B.; Martin, R.E.; Wechsler, D. Evaluation of a flow-photochemistry platform for the synthesis of compact modules. Tetrahedron Lett. 2012, 53, 1363-1366. [CrossRef]

144. Aillet, T.; Loubiere, K.; Dechy-Cabaret, O.; Prat, L. Photochemical synthesis of a "cage" compound in a microreactor: Rigorous comparison with a batch photoreactor. Chem. Eng. Process. Process Intensif. 2013, 64, 38-47. [CrossRef]

145. El Zanati, E.; Abdallah, H.; Elnahas, G. Micro-reactor for non-catalyzed esterification reaction: Performance and modeling. Int. J. Chem. React. Eng. 2017, 15. [CrossRef]

146. Inoue, T.; Ohtaki, K.; Murakami, S.; Matsumoto, S. Direct synthesis of hydrogen peroxide based on microreactor technology. Fuel Process. Technol. 2013, 108, 8-11. [CrossRef]

147. Freakley, S.J.; Piccinini, M.; Edwards, J.K.; Ntainjua, E.N.; Moulijn, J.A.; Hutchings, G.J. Effect of reaction conditions on the direct synthesis of hydrogen peroxide with a AuPd/TiO2 catalyst in a flow reactor. ACS Catal. 2013, 3, 487-501. [CrossRef]

148. Paunovic, V.; Schouten, J.C.; Nijhuis, T. Direct synthesis of hydrogen peroxide in a wall-coated microchannel reactor over Au-Pd catalyst: A performance study. Catal. Today 2015, 248, 160-168. [CrossRef]

149. Westermann, T.; Mleczko, L. Heat management in microreactors for fast exothermic organic syntheses first design principles. Org. Process Res. Dev. 2016, 20, 487-494. [CrossRef]

150. Kulkarni, A.A. Continuous flow nitration in miniaturized devices. Beilstein J. Org. Chem. 2014, 10, 405-424. [CrossRef]

151. Aida, T.M.; Oshima, M.; Smith Jr, R.L. Controlled conversion of proteins into high-molecular-weight peptides without additives with high-temperature water and fast heating rates. ACS Sustain. Chem. Eng. 2017, 5 , 7709-7715. [CrossRef]

152. Reichart, B.; Tekautz, G.; Kappe, C.O. Continuous flow synthesis of n-alkyl chlorides in a high-temperature microreactor environment. Org. Process Res. Dev. 2013, 17, 152-157. [CrossRef]

153. Min, K.I.; Lee, H.J.; Kim, D.P. Three-dimensional flash flow microreactor for scale-up production of monodisperse PEG-PLGA nanoparticles. Lab Chip 2014, 14, 3987-3992. [CrossRef] [PubMed]

154. Wang, C.W.; Sinton, D.; Moffitt, M.G. Morphological control via chemical and shear forces in block copolymer self-assembly in the lab-on-chip. ACS Nano 2013, 7, 1424-1436. [CrossRef]

155. Bains, A.; Cao, Y.; Kly, S.; Wulff, J.E.; Moffitt, M.G. Controlling structure and function of polymeric drug delivery nanoparticles using microfluidics. Mol. Pharm. 2017, 14, 2595-2606. [CrossRef] [PubMed]

156. Bains, A.; Wulff, J.E.; Moffitt, M.G. Microfluidic synthesis of dye-loaded polycaprolactone-block-poly (ethylene oxide) nanoparticles: Insights into flow-directed loading and in vitro release for drug delivery. J. Colloid Interface Sci. 2016, 475, 136-148. [CrossRef]

157. Corrigan, N.; Rosli, D.; Jones, J.W.J.; Xu, J.; Boyer, C. Oxygen tolerance in living radical polymerization: Investigation of mechanism and implementation in continuous flow polymerization. Macromolecules 2016, 49, 6779-6789. [CrossRef]

158. Daniloska, V.; Carretero, P.; Tomovska, R.; Asua, J.M. High performance pressure sensitive adhesives by miniemulsion photopolymerization in a continuous tubular reactor. Polymer 2014, 55, 5050-5056. [CrossRef]

159. Tomovska, R.; de la Cal, J.C.; Asua, J.M. Miniemulsion photo-copolymerization of styrene/butyl acrylate in a continuous tubular reactor. Ind. Eng. Chem. Res. 2014, 53, 7313-7320. [CrossRef]

160. Qiu, M.; Zha, L.; Song, Y.; Xiang, L.; Su, Y. Numbering-up of capillary microreactors for homogeneous processes and its application in free radical polymerization. React. Chem. Eng. 2019, 4, 351-361. [CrossRef]

161. Su, Y.; Song, Y.; Xiang, L. Continuous-flow Microreactors for polymer synthesis: Engineering principles and applications. In Accounts on Sustainable Flow Chemistry; Noël, T., Luque, R., Eds.; Springer International Publishing: Cham, Switzerland, 2020; pp. 147-190.

162. Yoshida, J.; Nagaki, A.; Iwasaki, T.; Suga, S. Enhancement of chemical selectivity by microreactors. Chem. Eng. Technol. 2005, 28, 259-266. [CrossRef] 
163. Watts, P.; Wiles, C. Micro reactors: A new tool for the synthetic chemist. Org. Biomol. Chem. 2007, 5, 727-732. [CrossRef] [PubMed]

164. Watts, P.; Wiles, C. Micro reactors, flow reactors and continuous flow synthesis. J. Chem. Res. 2012, 36, 181-193. [CrossRef]

165. Watkins, N.N.; Hassan, U.; Damhorst, G.; Ni, H.; Vaid, A.; Rodriguez, W.; Bashir, R. Microfluidic CD4+ and CD8+ T lymphocyte counters for point-of-care HIV diagnostics using whole blood. Sci. Transl. Med. 2013, 5, 214ra170. [CrossRef] [PubMed]

166. Yetisen, A.K.; Akram, M.S.; Lowe, C.R. Based microfluidic point-of-care diagnostic devices. Lab Chip 2013, 13, 2210-2251. [CrossRef]

167. Marques, M.P.; Fernandes, P.; Cabral, J.M.; Žnidaršič-Plazl, P.; Plazl, I. Continuous steroid biotransformations in microchannel reactors. New Biotechnol. 2012, 29, 227-234. [CrossRef]

168. Gumel, A.M.; Annuar, M. Thermomyces lanuginosus lipase-catalyzed synthesis of natural flavor esters in a continuous flow microreactor. 3 Biotech 2016, 6, 24. [CrossRef]

169. Wu, W.I.; Sask, K.N.; Brash, J.L.; Selvaganapathy, P.R. Polyurethane-based microfluidic devices for blood contacting applications. Lab Chip 2012, 12, 960-970. [CrossRef]

170. Porta, R.; Benaglia, M.; Puglisi, A. Flow chemistry: Recent developments in the synthesis of pharmaceutical products. Org. Process Res. Dev. 2016, 20, 2-25. [CrossRef]

171. Khodashenas, B.; Zadghaffari, R.; Jafari, S.D. Process intensification approach for the synthesis of metal nanoparticles: A mini review. Orient. J. Chem. 2015, 31, 249-257. [CrossRef]

172. Su, M. Synthesis of highly monodisperse silica nanoparticles in the microreactor system. Korean J. Chem. Eng. 2017, 34, 484-494. [CrossRef]

173. Bolivar, J.M.; Wiesbauer, J.; Nidetzky, B. Biotransformations in microstructured reactors: More than flowing with the stream? Trends Biotechnol. 2011, 29, 333-342. [CrossRef] [PubMed]

174. Zhao, C.-X.; He, L.; Qiao, S.Z.; Middelberg, A.P.J. Nanoparticle synthesis in microreactors. Chem. Eng. Sci. 2011, 66, 1463-1479. [CrossRef]

175. Nightingale, A.M.; deMello, J.C. Segmented flow reactors for nanocrystal synthesis. Adv. Mater. 2013, 25, 1813-1821. [CrossRef] [PubMed]

176. Lignos, I.; Protesescu, L.; Stavrakis, S.; Piveteau, L.; Speirs, M.J.; Loi, M.A.; Kovalenko, M.V.; de Mello, A.J. Facile droplet-based microfluidic synthesis of monodisperse IV-VI semiconductor nanocrystals with coupled in-line NIR fluorescence detection. Chem. Mater. 2014, 26, 2975-2982. [CrossRef]

177. Gutierrez, L.; Gomez, L.; Irusta, S.; Arruebo, M.; Santamaria, J. Comparative study of the synthesis of silica nanoparticles in micromixer-microreactor and batch reactor systems. Chem. Eng. J. 2011, 171, 674-683. [CrossRef]

178. Ju, J.; Zeng, C.; Zhang, L.; Xu, N. Continuous synthesis of zeolite NaA in a microchannel reactor. Chem. Eng. J. 2006, 116, 115-121. [CrossRef]

179. Appalakutti, S.; Sonawane, S.; Bhanvase, B.A.; Mittal, V.; Ashokkumar, M. Process intensification of copper chromite (CuCr2O4) nanoparticle production using continuous flow microreactor. Chem. Eng. Process. Process Intensif. 2015, 89, 28-34. [CrossRef]

180. Azimi, N.; Rahimi, M.; Abdollahi, N. Using magnetically excited nanoparticles for liquid-liquid two-phase mass transfer enhancement in a Y-type micromixer. Chem. Eng. Process. Process Intensif. 2015, 97, 12-22. [CrossRef]

181. Wang, Y.; Zhang, X.; Wang, A.; Li, X.; Wang, G.; Zhao, L. Synthesis of ZnO nanoparticles from microemulsions in a flow type microreactor. Chem. Eng. J. 2014, 235, 191-197. [CrossRef]

182. Du, L.; Wang, Y.J.; Lu, Y.C.; Luo, G.S. Process intensification of BaSO4 nanoparticle preparation with agitation of microbubbles. Powder Technol. 2013, 247, 60-68. [CrossRef]

183. Lesmana, D.; Wu, H.S. $\mathrm{Cu} / \mathrm{ZnO} / \mathrm{Al} 2 \mathrm{O} 3 / \mathrm{Cr} 2 \mathrm{O} 3 / \mathrm{CeO} 2$ catalyst for hydrogen production by oxidative methanol reforming via washcoat catalyst preparation in microchannel reactor. Bull. Chem. React. Eng. Catal. 2017, 12, 384-392. [CrossRef]

184. Günther, A.; Jensen, K.F. Multiphase microfluidics: From flow characteristics to chemical and materials synthesis. Lab Chip 2006, 6, 1487-1503. [CrossRef]

185. Aubin, J.; Ferrando, M.; Jiricny, V. Current methods for characterising mixing and flow in microchannels. Chem. Eng. Sci. 2010, 65, 2065-2093. [CrossRef] 
186. Kjeang, E.; Michel, R.; Harrington, D.A.; Sinton, D.; Djilali, N. An alkaline microfluidic fuel cell based on formate and hypochlorite bleach. Electrochim. Acta 2008, 54, 698-705. [CrossRef]

187. Bamgbopa, M.O.; Almheiri, S.; Sun, H. Prospects of recently developed membraneless cell designs for redox flow batteries. Renew. Sustain. Energy Rev. 2017, 70, 506-518. [CrossRef]

188. Suss, M.E.; Conforti, K.; Gilson, L.; Buie, C.R.; Bazant, M.Z. Membraneless flow battery leveraging flow-through heterogeneous porous media for improved power density and reduced crossover. RSC Adv. 2016, 6, 100209-100213. [CrossRef]

189. Hollinger, A.S.; Kenis, P.J.A. Electrohydrodynamic-jet deposition of pt-based fuel cell catalysts. In International Conference on Fuel Cell Science, Engineering and Technology; American Society of Mechanical Engineers: New York, NY, USA, 2016.

190. Zebda, A.; Renaud, L.; Cretin, M.; Pichot, F.; Innocent, C.; Ferrigno, R.; Tingry, S. A microfluidic glucose biofuel cell to generate micropower from enzymes at ambient temperature. Electrochem. Commun. 2009, 11, 592-595. [CrossRef]

191. Choban, E.R.; Spendelow, J.S.; Gancs, L.; Wieckowski, A.; Kenis, P.J.A. Membraneless laminar flow-based micro fuel cells operating in alkaline, acidic, and acidic/alkaline media. Electrochimica Acta 2005, 50, 5390-5398. [CrossRef]

192. Zou, H.; Chen, J.; Fang, Y.; Ding, J.; Peng, W.; Liu, R. A dual-electrolyte based air-breathing regenerative microfluidic fuel cell with $1.76 \mathrm{~V}$ open-circuit-voltage and $0.74 \mathrm{~V}$ water-splitting voltage. Nano Energy 2016, 27, 619-626. [CrossRef]

193. Lalaoui, N.; Means, N.; Walgama, C.; Le Goff, A.; Holzinger, M.; Krishnan, S.; Cosnier, S. Enzymatic versus electrocatalytic oxidation of NADH at carbon-nanotube electrodes modified with glucose dehydrogenases: Application in a bucky-paper-based glucose enzymatic fuel cell. ChemElectroChem 2016, 3, 2058-2062. [CrossRef]

194. Rasmussen, M.; Abdellaoui, S.; Minteer, S.D. Enzymatic biofuel cells: 30 years of critical advancements. Biosens. Bioelectron. 2016, 76, 91-102. [CrossRef] [PubMed]

195. Kjeang, E.; Brolo, A.G.; Harrington, D.A.; Djilali, N.; Sinton, D. Hydrogen peroxide as an oxidant for microfluidic fuel cells. J. Electrochem. Soc. 2007, 154, B1220. [CrossRef]

196. Oruc, M.E.; Desai, A.V.; Nuzzo, R.G.; Kenis, P.J.A. Design, fabrication, and characterization of a proposed microchannel water electrolyzer. J. Power Sources 2016, 307, 122-128. [CrossRef]

197. Terrier, O.; Bourdon, J.-C.; Rosa-Calatrava, M. Method for Improving the Production of Influenza Viruses and Vaccine Seeds. U.S. Patent No. US938,123,8B2, 5 July 2016.

198. Narvaez Villarrubia, C.W.; Soavi, F.; Santoro, C.; Arbizzani, C.; Serov, A.; Rojas-Carbonell, S.; Gupta, G.; Atanassov, P. Self-feeding paper based biofuel cell/self-powered hybrid $\mu$-supercapacitor integrated system. Biosens. Bioelectron. 2016, 86, 459-465. [CrossRef]

199. Kim, C.J.; Hur, J.; Meng, D. Self-Pumping Membraneless Fuel Cell. U.S. Patent No. US960,178,9B2, 21 March 2017.

200. Verma, R.; Lal, S.; Deepa, M.; Janardhanan, V.M.; Sahu, K.C. Sodium percarbonate based, mixed-media fuel cells supported on paper with gold/nickel oxide catalysts. ChemElectroChem 2017, 4, 310-319. [CrossRef]

201. Li, L.; Fan, W.; Xuan, J.; Leung, M.K.H.; Zheng, K.; She, Y. Design principles of current collectors in microfluidic fuel cell with flow-through porous electrodes. Energy Procedia 2017, 105, 1557-1563. [CrossRef]

202. Kwok, Y.H.; Tsang, A.C.H.; Wang, Y.; Leung, D.Y.C. Ultra-fine Pt nanoparticles on graphene aerogel as a porous electrode with high stability for microfluidic methanol fuel cell. J. Power Sources 2017, 349, 75-83. [CrossRef]

203. Ojani, R.; Hamidi, P.; Raoof, J.-B. Efficient nonenzymatic hydrogen peroxide sensor in acidic media based on Prussian blue nanoparticles-modified poly(o-phenylenediamine)/glassy carbon electrode. Chin. Chem. Lett. 2016, 27, 481-486. [CrossRef]

204. Qian, W.; Wilkinson, D.P.; Shen, J.; Wang, H.; Zhang, J. Architecture for portable direct liquid fuel cells. J. Power Sources 2006, 154, 202-213. [CrossRef]

205. Whitesides, G.M. The origins and the future of microfluidics. Nature 2006, 442, 368. [CrossRef] [PubMed]

206. Lauga, E.; Brenner, M.; Stone, H. Microfluidics: The no-slip boundary condition. In Springer Handbook of Experimental Fluid Mechanics; Tropea, C., Yarin, A.L., Foss, J.F., Eds.; Springer: Berlin/Heidelberg, Germany, 2007; pp. 1219-1240. 
207. Choi, S.D.; Choi, J.H.; Kim, Y.H.; Kim, S.Y.; Dwivedi, P.K.; Sharma, A.; Goel, S.; Kim, G.M. Enzyme immobilization on microelectrode arrays of CNT/Nafion nanocomposites fabricated using hydrogel microstencils. Microelectron. Eng. 2015, 141, 193-197. [CrossRef]

208. Ramasamy, R.P. Photosynthetic Electrochemical Cells. U.S. Patent No. 1,005,665,9B2, 21 August 2018.

209. Minteer, S.D.; Martin, R.S.; Moore, C.M. Microfluidic Biofuel Cell. Google Patents No. 7,709,134, 4 May 2010.

210. Bedekar, A.; Feng, J.; Lim, K.; Krishnamoorthy, S.; Palmore, G.; Sundaram, S. In Proceedings of the Computational Analysis of Microfluidic Biofuel Cells, Austin, TX, USA, 7-12 November 2004.

211. Ding, S.-N.; Holzinger, M.; Mousty, C.; Cosnier, S. Laccase electrodes based on the combination of single-walled carbon nanotubes and redox layered double hydroxides: Towards the development of biocathode for biofuel cells. J. Power Sources 2010, 195, 4714-4717. [CrossRef]

212. Lee, J.Y.; Shin, H.Y.; Kang, S.W.; Park, C.; Kim, S.W. Application of an enzyme-based biofuel cell containing a bioelectrode modified with deoxyribonucleic acid-wrapped single-walled carbon nanotubes to serum. Enzym. Microb. Technol. 2011, 48, 80-84. [CrossRef]

213. Amatore, C.; Da Mota, N.; Lemmer, C.; Pebay, C.; Sella, C.; Thouin, L. Theory and experiments of transport at channel microband electrodes under laminar flows. 2. electrochemical regimes at double microband assemblies under steady state. Anal. Chem. 2008, 80, 9483-9490. [CrossRef] [PubMed]

(C) 2020 by the authors. Licensee MDPI, Basel, Switzerland. This article is an open access article distributed under the terms and conditions of the Creative Commons Attribution (CC BY) license (http://creativecommons.org/licenses/by/4.0/). 